\title{
Duodeno-pancreatic and extrahepatic biliary tree trauma: WSES-AAST guidelines
}

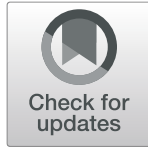

\author{
Federico Coccolini ${ }^{1 *}$ (D), Leslie Kobayashi ${ }^{2}$, Yoram Kluger ${ }^{3}$, Ernest E. Moore ${ }^{4}$, Luca Ansaloni ${ }^{5}$, Walt Biffl' ${ }^{6}$, \\ Ari Leppaniemi ${ }^{7}$, Goran Augustin ${ }^{8}$, Viktor Reva ${ }^{9}$, Imitiaz Wani ${ }^{10}$, Andrew Kirkpatrick ${ }^{11}$, Fikri Abu-Zidan ${ }^{12}$, \\ Enrico Cicuttin ${ }^{5}$, Gustavo Pereira Fraga ${ }^{13}$, Carlos Ordonez $^{14}$, Emmanuil Pikoulis ${ }^{15}$, Maria Grazia Sibilla ${ }^{5}$, Ron Maier ${ }^{16}$, \\ Yosuke Matsumura ${ }^{17}$, Peter T. Masiakos ${ }^{18}$, Vladimir Khokha ${ }^{19}$, Alain Chichom Mefire ${ }^{20}$, Rao Ivatury ${ }^{21}$, \\ Francesco Favi ${ }^{5}$, Vassil Manchev ${ }^{22}$, Massimo Sartelli ${ }^{23}$, Fernando Machado ${ }^{24}$, Junichi Matsumoto ${ }^{25}$, \\ Massimo Chiarugi ${ }^{1}$, Catherine Arvieux ${ }^{26}$, Fausto Catena ${ }^{27}$, Raul Coimbra ${ }^{28}$ and WSES-AAST Expert Panel
}

\begin{abstract}
Duodeno-pancreatic and extrahepatic biliary tree injuries are rare in both adult and pediatric trauma patients, and due to their anatomical location, associated injuries are very common. Mortality is primarily related to associated injuries, but morbidity remains high even in isolated injuries. Optimal management of duodeno-bilio-pancreatic injuries is dictated primarily by hemodynamic stability, clinical presentation, and grade of injury. Endoscopic and percutaneous interventions have increased the ability to non-operatively manage these injuries. Late diagnosis and treatment are both associated to increased morbidity and mortality. Sequelae of late presentations of pancreatic injury and complications of severe pancreatic trauma are also increasingly addressed endoscopically and with interventional radiology procedures. However, for moderate and severe extrahepatic biliary and severe duodenopancreatic injuries, immediate operative intervention is preferred as associated injuries are frequent and commonly present with hemodynamic instability or peritonitis. The aim of this paper is to present the World Society of Emergency Surgery (WSES) and American Association for the Surgery of Trauma (AAST) duodenal, pancreatic, and extrahepatic biliary tree trauma management guidelines.
\end{abstract}

Keywords: Pancreas, Bile duct, Biliary tree, Ampulla, Duodenum, Trauma, Adult, Pediatric, Classification, Guidelines, Injury, Surgery, Operative, Non-operative, Conservative, Endoscopic retrograde cholangiopancreatography (ERCP), Endoscopy

\section{Background}

Duodeno-pancreatic and extrahepatic biliary tree injuries are, by definition, transitional lesions that may involve one or more anatomical structures. Their management is multidisciplinary. The initial phase is best managed by trauma or emergency surgeons but the late reconstructive phase should involve hepatobiliary surgeons. Moreover, endoscopy, interventional radiology, and gastroenterology may be involved to improve success of non-operative management (NOM) and to manage early and late sequelae of injury and complications. Transition of treatment

\footnotetext{
* Correspondence: federico.coccolini@gmail.com

${ }^{1}$ General, Emergency and Trauma Surgery Department, Pisa University

Hospital, Via Paradisa, 2, 56124 Pisa, Italy

Full list of author information is available at the end of the article
}

strategies should occur as quickly and seamlessly as possible as morbidity and mortality both increase with delays in treatment.

Adult duodenal trauma has an incidence of $0.2-0.6 \%$ of all trauma patients and $1-4.7 \%$ of all cases of abdominal trauma [1-3]. Pediatric duodenal trauma is also rare, occurring in $<1 \%$ of all pediatric trauma and $2-10 \%$ of children with abdominal trauma [4-6]. Associated injuries are present in $68-86.5 \%$ of patients, with major vascular injury occurring in $23-40 \%$ of cases. Presence and type of associated injuries greatly impact the treatment of duodenal trauma [1, 2, 7-12]. Penetrating trauma is the most common cause of duodenal injury (DI) in adult patients, accounting for $53.6-90 \%$ of cases $[2,8-10,12,13]$. Pediatric DI is most frequently due to blunt trauma which

(c) The Author(s). 2019 Open Access This article is distributed under the terms of the Creative Commons Attribution 4.0 International License (http://creativecommons.org/licenses/by/4.0/), which permits unrestricted use, distribution, and 
occurs in $70-78 \%$ of cases. Non-accidental trauma, motor vehicle crashes, and bicycle/handle bar injuries are the most common causes of pediatric DI [4-6]. Male gender is more commonly affected in both adult and pediatric DI.

Adult pancreatic injury (PI) is rare, occurring in less than $1 \%$ of all traumas and $3.7-11 \%$ of abdominal trauma [1-7]. Pediatric PI is also rare occurring in $<1 \%$ of children $[8,9]$. Blunt trauma is the most common cause among both adults and children accounting for $61.1-89 \%$ of cases in most series, with motor vehicle and bicycle crashes being the most frequent causes $[5,6,10-16]$. However, penetrating mechanisms are much more common in studies from South Africa, North America, and the military [2-4]. Associated injuries are frequent, occurring in $55-100 \%$ of cases, and are more common in patients requiring surgery and following penetrating mechanisms of injury $[1,3,6,11,12$, $14,17]$. Male gender is more commonly affected, accounting for $63-79 \%$ of adults and $57-73 \%$ of pediatric PI $[3,5$, $6,8,10-12,14-16]$.

Extrahepatic biliary tree injury (EHBTI) is even rarer than pancreatic injury. EHBTI occurs in $0.1 \%$ of adult and $0.009 \%$ of pediatric trauma. Isolated EHBTI is extremely rare occurring in only $2-3 \%$ of cases [18-21]. The most frequently associated injuries include the liver, pancreas, and duodenum. Blunt trauma is more common than penetrating for all EHBTI except the gallbladder, which is more frequently injured due to penetrating mechanisms [18, 21, 22]. Management of EHBTI in both adults and children is primarily dictated by associated injuries and injury grade. The majority of EHBTI will require surgical or endoscopic management.

\section{Notes on the use of the guidelines}

The guidelines are evidence-based, with the grade of recommendation based on the evidence. The guidelines present the diagnostic and therapeutic methods for optimal management of duodenal-bilio-pancreatic trauma. The practice guidelines promulgated in this work does not represent a standard of practice. They are suggested plans of care, based on best available evidence and the consensus of experts, but they do not exclude other approaches as being within the standard of practice. For example, they should not be used to compel adherence to a given method of medical management, which method should be finally determined after taking account of the conditions at the relevant medical institution (staff levels, experience, equipment, etc.) and the characteristics of the individual patient. However, responsibility for the results of treatment rests with those who are directly engaged therein, and not with the consensus group.

\section{Methods}

A computerized search was done by the bibliographer in different databanks (MEDLINE, Scopus, EMBASE). Citations were included for the period between January 1990 and March 2019 using the primary search strategy: duodenum, pancreas, bile duct, biliary tree, ampulla, trauma, adult, paediatric, classification, guidelines, injury, surgery, diagnosis, follow-up, operative, non-operative, conservative, endoscopic retrograde cholangiopancreatography (ERCP), endoscopic, management, combined with AND/OR. No search restrictions were imposed. The dates were selected to allow comprehensively published abstracts of clinical trials, consensus conference, comparative studies, congresses, guidelines, government publication, multicenter studies, systematic reviews, meta-analysis, large case series, original articles, and randomized controlled trials. Research details are summarized in Fig. 1. The level of evidence (LE) was evaluated using the GRADE system (Table 1) [23]. A group of experts in the field coordinated by a central coordinator was contacted to express their evidence-based opinion on several issues about the pediatric ( $<16$ years old) and adult duodeno-pancreatic and extrahepatic biliary tree trauma. Through the Delphi process, the different issues were discussed in subsequent rounds. The central coordinator assembled the different answers derived from each round. Each version was then revised and improved. The definitive version was discussed during the World Society of Emergency Surgery (WSES) World Congress held in June 2019 in Njimengen, The Netherlands, by a combined WSESAmerican Association for the Surgery for Trauma (AAST) expert group. The final version in which the agreement was reached resulted in the present manuscript. Statements are summarized in Table 2.

\section{Definitions}

In adults patients, hemodynamic instability is considered the condition in which admission systolic blood pressure is $<90 \mathrm{mmHg}$ with evidence of skin vasoconstriction (cool, clammy, decreased capillary refill), altered level of consciousness and/or shortness of breath, or $>90 \mathrm{mmHg}$ but requiring bolus infusions/transfusions and/or vasopressor drugs and/or admission base excess $(\mathrm{BE})>-5$ $\mathrm{mmol} / \mathrm{L}$ and/or shock index $>1$ and/or transfusion requirement of at least 4-6 $\mathrm{U}$ of packed red blood cells within the first $24 \mathrm{~h}$. Transient responder patients (adult and pediatric) are those showing an initial response to adequate fluid resuscitation, but then subsequent signs of ongoing blood loss and perfusion deficits. These patients have an initial response to therapy but do not reach sufficient stabilization to undergo interventional radiology procedures or NOM.

In pediatric patients, hemodynamic stability is considered a systolic blood pressure of $90 \mathrm{mmHg}$ plus twice the child's age in years (the lower limit is inferior to 70 $\mathrm{mmHg}$ plus twice the child's age in years, or inferior to $50 \mathrm{mmHg}$ in some studies). An acceptable hemodynamic status in children is considered a positive response to fluid resuscitation: 3 boluses of $20 \mathrm{~mL} / \mathrm{kg}$ of crystalloid 


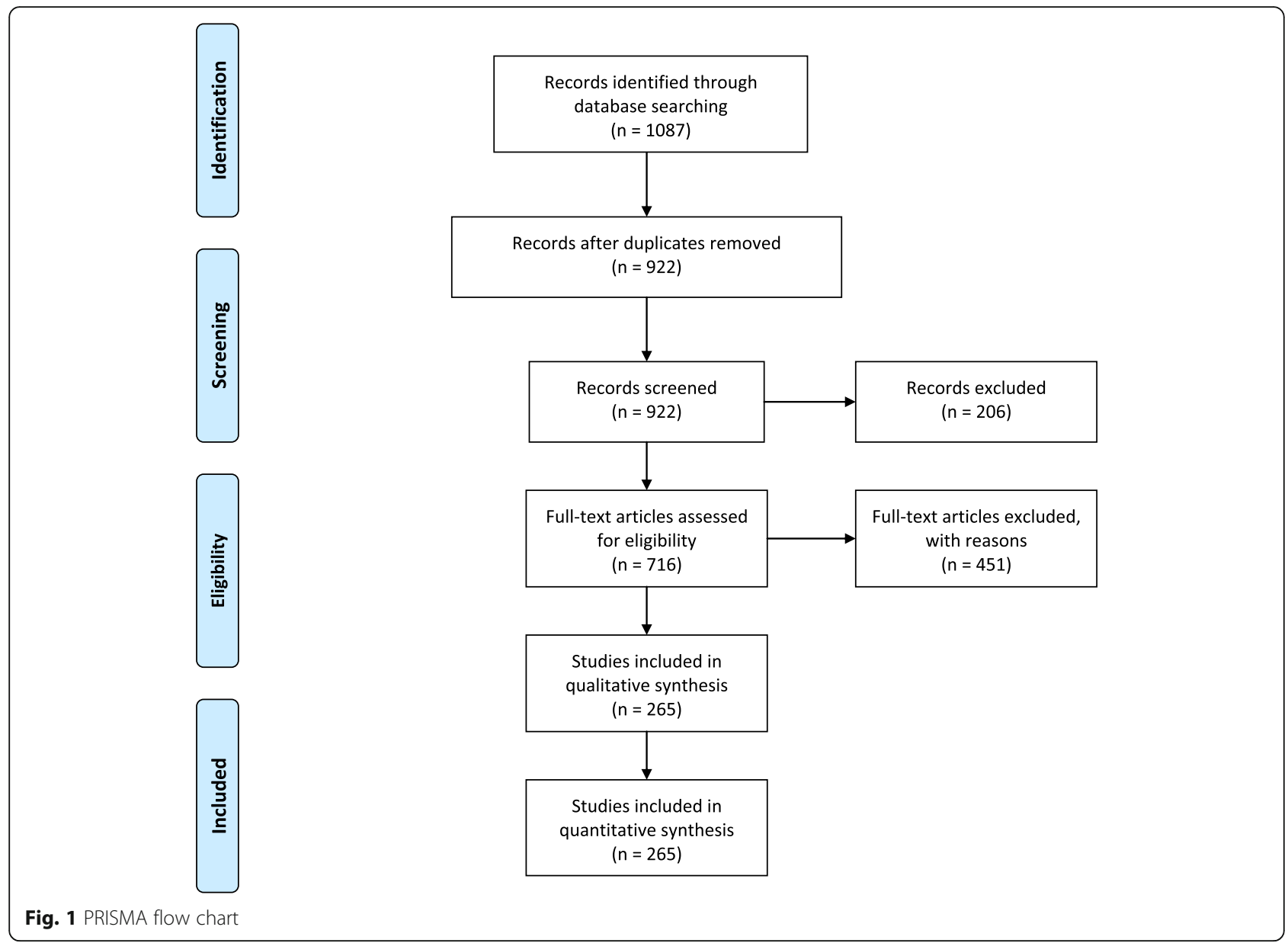

replacement should be administered before blood replacement leading to heart rate reduction, cleared sensorium, return of peripheral pulses, normal skin color, increase in blood pressure and urinary output, and an increase in warmth of the skin in the extremities. Clinical judgment, however, is fundamental in evaluating children.

\section{WSES classification}

The WSES classification divides duodenum, pancreas, and extrahepatic biliary tree injuries into four classes considering the AAST-OIS classification (Tables 3, 4, and 5) and the hemodynamic status (the final grade of the lesion depends on the higher grade lesion among the duodenal, pancreatic, and extrahepatic biliary tree) (Table 6):

- Minor (WSES class I)

- Moderate (WSES class II)

- Severe (WSES classes III and IV)

Minor duodeno-pancreatic and extrahepatic biliary tree injuries:

- WSES class I includes:
- AAST-OIS grade I duodenal lesions

- AAST-OIS grade I-II pancreatic lesions

- AAST-OIS grade I-III extrahepatic biliary

lesions

Moderate duodeno-pancreatic and extrahepatic biliary tree injuries:

- WSES class II includes:

- AAST-OIS grade II duodenal lesions

- AAST-OIS grade III pancreatic lesions

- AAST-OIS grade IV extrahepatic biliary lesions

Severe duodeno-pancreatic and extrahepatic biliary tree injuries:

- WSES class III includes:

- AAST-OIS grade III-IV-V duodenal lesions

- AAST-OIS grade IV-V pancreatic lesions

- AAST-OIS grade V extrahepatic biliary tree lesions

- WSES class IV includes hemodynamically unstable AAST-OIS grade I-V duodeno-biliopancreatic lesions 
Table 1 GRADE system to evaluate the level of evidence and recommendation

\begin{tabular}{|c|c|c|c|}
\hline Grade of recommendation & Clarity of risk/benefit & Quality of supporting evidence & Implications \\
\hline \multicolumn{4}{|l|}{$1 \mathrm{~A}$} \\
\hline $\begin{array}{l}\text { Strong recommendation, } \\
\text { high-quality evidence }\end{array}$ & $\begin{array}{l}\text { Benefits clearly outweigh risk } \\
\text { and burdens, or vice versa }\end{array}$ & $\begin{array}{l}\text { RCTs without important limitations } \\
\text { or overwhelming evidence from } \\
\text { observational studies }\end{array}$ & $\begin{array}{l}\text { Strong recommendation, applies to } \\
\text { most patients in most circumstances } \\
\text { without reservation }\end{array}$ \\
\hline \multicolumn{4}{|l|}{$1 \mathrm{~B}$} \\
\hline $\begin{array}{l}\text { Strong recommendation, } \\
\text { moderate-quality evidence }\end{array}$ & $\begin{array}{l}\text { Benefits clearly outweigh risk } \\
\text { and burdens, or vice versa }\end{array}$ & $\begin{array}{l}\text { RCTs with important limitations } \\
\text { (inconsistent results, methodological } \\
\text { flaws, indirect analyses, or imprecise } \\
\text { conclusions) or exceptionally strong } \\
\text { evidence from observational studies }\end{array}$ & $\begin{array}{l}\text { Strong recommendation, applies to } \\
\text { most patients in most circumstances } \\
\text { without reservation }\end{array}$ \\
\hline \multicolumn{4}{|l|}{$1 C$} \\
\hline $\begin{array}{l}\text { Strong recommendation, } \\
\text { low-quality or very low-quality } \\
\text { evidence }\end{array}$ & $\begin{array}{l}\text { Benefits clearly outweigh risk } \\
\text { and burdens, or vice versa }\end{array}$ & Observational studies or case series & $\begin{array}{l}\text { Strong recommendation but subject } \\
\text { to change when higher quality } \\
\text { evidence becomes available }\end{array}$ \\
\hline \multicolumn{4}{|l|}{$2 \mathrm{~A}$} \\
\hline $\begin{array}{l}\text { Weak recommendation, } \\
\text { high-quality evidence }\end{array}$ & $\begin{array}{l}\text { Benefits closely balanced with } \\
\text { risks and burden }\end{array}$ & $\begin{array}{l}\text { RCTs without important limitations } \\
\text { or overwhelming evidence from } \\
\text { observational studies }\end{array}$ & $\begin{array}{l}\text { Weak recommendation, best action } \\
\text { may differ depending on the } \\
\text { patient, treatment circumstances, or } \\
\text { social values }\end{array}$ \\
\hline \multicolumn{4}{|l|}{$2 \mathrm{~B}$} \\
\hline $\begin{array}{l}\text { Weak recommendation, } \\
\text { moderate-quality evidence }\end{array}$ & $\begin{array}{l}\text { Benefits closely balanced with } \\
\text { risks and burden }\end{array}$ & $\begin{array}{l}\text { RCTs with important limitations } \\
\text { (inconsistent results, methodological } \\
\text { flaws, indirect, or imprecise) or } \\
\text { exceptionally strong evidence } \\
\text { from observational studies }\end{array}$ & $\begin{array}{l}\text { Weak recommendation, best action } \\
\text { may differ depending on the } \\
\text { patient, treatment circumstances, or } \\
\text { social values }\end{array}$ \\
\hline \multicolumn{4}{|l|}{$2 \mathrm{C}$} \\
\hline $\begin{array}{l}\text { Weak recommendation, } \\
\text { low-quality or very low-quality } \\
\text { evidence }\end{array}$ & $\begin{array}{l}\text { Uncertainty in the estimates } \\
\text { of benefits, risks, and burden; } \\
\text { benefits, risk, and burden may } \\
\text { be closely balanced }\end{array}$ & Observational studies or case series & $\begin{array}{l}\text { Very weak recommendation; } \\
\text { alternative treatments may be } \\
\text { equally reasonable and merit } \\
\text { consideration }\end{array}$ \\
\hline
\end{tabular}

Based on present classification, WSES and AAST suggest a diagnostic and management algorithm (Figs. 2 and 3 , respectively).

\section{Diagnosis}

- Management of pediatric patients with duodenalpancreatic trauma requires specific skills; only trauma centers should take care of this cohort of patients. (GoR 1C)

- The choice of diagnostic technique at admission must be based on the hemodynamic status.

(GoR 1A)

- Extended-Focused Assessment with Sonography for Trauma (E-FAST) is rapid, repeatable, and effective for detecting free fluid and solid organ injury. (GoR 1A)

- Ultrasonography is not recommended to routinely diagnose duodeno-pancreatic trauma. Contrastenhanced ultrasonography may have a diagnostic role in stable trauma patients with suspected pancreatic injury. (GoR 2B)
- Repeated and combined measurement of serum amylase and lipase levels, starting from 3 to $6 \mathrm{~h}$ after the initial injury, is a useful tool to support clinical evaluation in suspicion of pancreatic injury. Elevated and/or increasing levels of serum amylase and lipase, in the absence of definitive diagnosis, are indications for more accurate investigation. (GoR 1B)

- Serial clinical examination is an important part of follow-up after biliary and pancreatic-duodenal trauma. (GoR 2A)

- CT-scan with intravenous contrast is essential in diagnosing duodeno-pancreatic injuries in hemodynamically stable or stabilized trauma patients. (GoR 1A)

- Administration of oral contrast material does not improve intravenous contrast-enhanced CT-scan sensitivity in detecting duodeno-pancreatic injuries. (GoR 2A)

- A repeat CT-scan within 12-24 h from the initial injury should be considered in hemodynamically stable patients with high clinical suspicion for duodeno-pancreatic injury or pancreatic ductal injury with negative CT- 
Table 2 Statement summary

\begin{tabular}{ll}
\hline Statements \\
\hline Diagnostic procedures & - Management of pediatric patients with duodenal-pancreatic trauma requires specific skills;
\end{tabular}
only trauma centers should take care of this cohort of patients. (GoR 1C)

- The choice of diagnostic technique at admission must be based on the hemodynamic status. (GoR 1A)

- E-FAST is rapid, repeatable, and effective for detecting free fluid and solid organ injury. (GoR 1A)

- Ultrasonography is not recommended to routinely diagnose duodeno-pancreatic trauma. Contrast-enhanced ultrasonography may have a diagnostic role in stable trauma patients with suspected pancreatic injury. (GoR 2B)

- Repeated and combined measurement of serum amylase and lipase levels, starting from 3 to $6 \mathrm{~h}$ after the initial injury, is a useful tool to support clinical evaluation in suspicion of pancreatic injury. Elevated and/or increasing levels of serum amylase and lipase, in absence of definitive diagnosis, are indications for more accurate investigation. (GoR 1B)

- Serial clinical examination is an important part of follow-up after biliary and pancreatic-duodenal trauma. (GoR 2A)

- CT-scan with intravenous contrast is essential in diagnosing duodeno-pancreatic injuries in hemodynamically stable or stabilized trauma patients. (GoR 1A)

- Administration of oral contrast material does not improve intravenous contrast-enhanced CT-scan sensitivity in detecting duodeno-pancreatic injuries. (GoR 2A)

- A repeat CT-scan within 12-24 h from the initial injury should be considered in hemodynamically stable patients with high clinical suspicion for duodeno-pancreatic injury or pancreatic ductal injury with negative CT-scan or non-specific CT findings on admission imaging, and/or elevated amylase and lipase, or persistent abdominal pain. (GoR 2A)

- Magnetic resonance cholangiopancreatography (MRCP) can be considered a second-line non-invasive diagnostic modality to definitely rule out pancreatic parenchymal and pancreatic ductal injuries. It should be considered for the diagnosis of suspected biliary injuries when performed with hepatobiliary contrast. (GoR 1B)

- In pediatric patients and pregnant women, to detect pancreatic parenchymal or pancreatic duct lesions, MRI is preferred if available in the emergency setting. (GoR 2A)

- In adult and pediatric patients, the risks associated with the radiation burden of CT should be balanced against the potential complications that may occur with a missed injury when alternative diagnostic modalities for pancreaticoduodenal injury are not available. (GoR 1C)

- Abdominal plain films using water-soluble contrast in the early trauma scenario are not recommended. (GoR 2A)

- Hepatobiliary scintigraphy is not recommended for detection of biliary leak in patients with suspected gallbladder and biliary injuries in the trauma setting. (GoR 2B)

- Diagnostic peritoneal lavage does not improve the specificity of diagnosing duodeno-pancreatic injury. It is sensitive but not specific for biliary tract injury. (GoR 2B)

- Exploratory laparotomy is indicated in hemodynamically unstable (WSES class IV) patients with a positive E-FAST. (GoR 1A)

- During surgical exploration of patients with abdominal trauma, the duodeno-pancreatic complex must be exposed and explored. (GoR 1A)

- During exploratory laparotomy, when biliary injury is suspected but not identified, an intraoperative cholangiogram is strongly recommended. (GoR 2A)

- In patients who are clinically suspected of having duodenal-pancreatic injuries, and are deteriorating clinically, if the imaging is equivocal, a diagnostic laparotomy should be performed. (GoR 2A)

- In suspected pancreatic duct and extrahepatic biliary tree injuries in hemodynamically stable or stabilized adults and pediatric patients, endoscopic retrograde cholangiopancreatography (ERCP) can be used for both diagnosis and treatment even in the early phase after trauma. (GoR 1B)

Non-operative management (NOM)

Duodenum

Pancreas, biliary tree
- Hemodynamic stability is the key factor in determining management strategy. (GoR 1C)

- Hemodynamically unstable (WSES class IV) patients should not be considered for NOM. (GoR 1C)

- NOM can be considered for hemodynamically stable or stabilized patients with duodenal wall hematomas (WSES class I-II, AAST-OIS grade I-II) in the absence of other abdominal organ injuries requiring surgery. (GoR 2B)

- Patients with progressive symptoms or worsening findings on repeat imaging should be considered failures of NOM. (GoR 2C)

- Hematomas initially treated with NOM should be considered for operative management if duodenal obstruction has not resolved within 14 days. (GoR 2C)

- NOM should be the treatment of choice for all hemodynamically stable or stabilized minor PI WSES class I (AAST grade I and some grade II) and gallbladder hematomas without perforation WSES class I (AAST grade I) in the absence of other abdominal injuries requiring surgery. (GoR 2C)

- Location of WSES class II (AAST grade III) PI is the primary determinant of treatment modality in hemodynamically stable adult patients. (GoR 2C) 
Table 2 Statement summary (Continued)

Operative management (OM)

Duodenum

Pancreas, biliary tree

Short- and long-term follow-up
Statements

- NOM may be considered only in selected hemodynamically stable or stabilized patients with WSES class II (AAST grade III) very proximal pancreatic body injuries in the absence of other abdominal injuries requiring surgery and only in higher level trauma centers; success of NOM may be increased with utilization of endoscopic and percutaneous interventions. (GoR 2C).

- Optimal management of hemodynamically stable or stabilized patients with WSES class III (AAST grade IV) PI is controversial. NOM management augmented by endoscopic or percutaneous interventions may be used in selected patients. (GoR 2C)

- NOM of WSES class III (AAST grade IV) injuries should be considered only in an environment that provides around the clock capability for patient intensive monitoring, an immediately available endoscopy and interventional radiology suite, $\mathrm{OR}$, and only in patients with stable or stabilized hemodynamic and absence of other abdominal injuries requiring surgery (GoR 2A).

- Sequelae of PI such as pancreatic fistulae and pseudocysts can frequently be addressed with image-guided percutaneous drain placement, endoscopic stenting, internal drainage, and endoscopic cyst-gastrostomy or cyst-jejunostomy. (GoR 2C)

- Hemodynamically unstable (WSES class IV) patients and those with peritonitis or bowel evisceration or impalement should undergo immediate operative intervention. (GoR 1C)

- Damage control techniques should be considered in hemodynamically unstable patients with DI, particularly those with associated injuries and physiologic derangement. (GoR 2B)

- Primary repair of DI should be considered whenever technically possible regardless of grade of injury. (GoR 2B)

- Ancillary procedures such as pyloric exclusion with and without gastrojejunostomy and biliary diversion may be considered in WSES class III or higher DI (AAST grades III, IV, and V). (GoR 2C)

- Lesions requiring pancreaticoduodenectomy (Whipple procedure) are often accompanied by severe associated injuries and shock. Damage control techniques and staged reconstruction in subsequent phases performed by experienced surgeons should be considered. (GoR 2C)

- In WSES class I (AAST grade I and some grade II) PI found during exploratory laparotomy, drainage may be considered (GoR 2B).

- Patients with distal WSES class II (AAST grade III) PI should undergo OM. (GoR 2C)

- Distal pancreatectomy (with or without splenectomy) is the procedure of choice for distal WSES class II (AAST grade III) PI. (GoR 2C)

- Pancreatoduodenectomy may be needed in patients with destructive injuries of the duodenal-pancreatic complex. In such cases, the operation has better results when performed in a staged fashion. Pancreato-jejunostomy or pancreato-gastrostomy reconstructions are equally effective in selected cases performed by experienced surgeons. (GoR 2C)

- In extrahepatic biliary tree WSES class I injuries (AAST grade I, II, and III) with laceration, perforation, or avulsion of the gallbladder, cholecystectomy is the treatment of choice. (GoR 1C)

- EHBT injuries undergoing an initial damage control procedure may be drained with delayed reconstruction performed as a staged approach. (GoR 2B)

- EHBT WSES class II-III (AAST grades IV and V) injuries should undergo reconstruction with hepaticojejunostomy or choledochojejunostomy if there is no associated vascular injury. (GoR 2C)

- NOM failure of EHBT WSES class II-III (AAST grades IV and V) injuries, hepaticojejunostomy should be considered during reconstruction. (GoR 2C)

- After discharge, the necessity for follow-up imaging should be driven by clinical symptoms (i.e., onset of abdominal distention, tenderness, fever, vomiting, jaundice). (GoR 2B)

- In adults, CT-scan is usually the first-line follow-up imaging tool for new-onset signs and symptoms. (GoR 2A)

- In pregnant females, the MRCP should be considered the diagnostic modality of choice for new-onset signs and symptoms, wherever available. (GoR 2A)

- In pediatric patients, ultrasound or contrast-enhanced US should be the diagnostic modality of choice for follow-up imaging. If cross-sectional imaging is required, MRI is preferred. (GoR 2A)

- Given the complexity and variability of traumatic injuries, the need for and choice of follow-up imaging should be made using a multidisciplinary approach. (GoR 2B) scan or non-specific CT findings on admission imaging, and/or elevated amylase and lipase, or persistent abdominal pain. (GoR 2A)
- Magnetic resonance cholangiopancreatography (MRCP) can be considered a second-line noninvasive diagnostic modality to definitely rule out 
Table 3 AAST organ injury scale for duodenal injuries

\begin{tabular}{|c|c|c|}
\hline Grade* $^{*}$ & Type of injury & Description of injury \\
\hline I & Hematoma & Involving single portion of duodenum \\
\hline & Laceration & Partial thickness, no perforation \\
\hline II & Hematoma & Involving more than one portion \\
\hline & Laceration & Disruption $<50 \%$ of circumference \\
\hline III & Laceration & $\begin{array}{l}\text { Disruption } 50 \%-75 \% \text { of circumference of D2 } \\
\text { Disruption } 50 \%-100 \% \text { of circumference of D1,D3,D4 }\end{array}$ \\
\hline IV & Laceration & $\begin{array}{l}\text { Disruption }>75 \% \text { of circumference of } \mathrm{D} 2 \\
\text { Involving ampulla or distal common bile duct }\end{array}$ \\
\hline V & $\begin{array}{l}\text { Laceration } \\
\text { Vascular }\end{array}$ & $\begin{array}{l}\text { Massive disruption of duodenopancreatic complex } \\
\text { Devascularization of duodenum }\end{array}$ \\
\hline
\end{tabular}

*Advances one grade for multiple injuries up to grade III. D1—first portion of duodenum; D2—second portion of duodenum; D3-third portion of duodenum; D4-fourth portion of duodenum)

pancreatic parenchymal and pancreatic ductal injuries. It should be considered for the diagnosis of suspected biliary injuries when performed with hepatobiliary contrast. (GoR 1B)

- In pediatric patients and pregnant women, to detect pancreatic parenchymal or pancreatic duct lesions, MRI is preferred if available in the emergency setting. (GoR 2A)

- In adult and pediatric patients, the risks associated with the radiation burden of $\mathrm{CT}$ should be balanced against the potential complications that may occur with a missed injury when alternative diagnostic modalities for pancreatico-duodenal injury are not available. (GoR 1C)
- Abdominal plain films using water-soluble contrast in the early trauma scenario are not recommended. (GoR 2A)

- Hepatobiliary scintigraphy is not recommended for detection of biliary leak in patients with suspected gallbladder and biliary injuries in the trauma setting. (GoR 2B)

- Diagnostic peritoneal lavage does not improve the specificity of diagnosing duodeno-pancreatic injury. It is sensitive but not specific for biliary tract injury. (GoR 2B)

- Exploratory laparotomy is indicated in hemodynamically unstable (WSES class IV) patients with a positive E-FAST. (GoR 1A)

Table 4 AAST organ injury scale for pancreatic injuries

\begin{tabular}{lll}
\hline Pancreas Injury Scale & \\
Grade $^{*}$ & Type of Injury & Description of Injury \\
\hline I & $\begin{array}{l}\text { Hematoma } \\
\text { Laceration }\end{array}$ & $\begin{array}{l}\text { Minor contusion without duct injury } \\
\text { Superficial laceration without duct injury }\end{array}$ \\
II & $\begin{array}{l}\text { Hematoma } \\
\text { Laceration }\end{array}$ & $\begin{array}{l}\text { Major contusion without duct injury or tissue loss } \\
\text { Major laceration without duct injury or tissue loss }\end{array}$ \\
III & Laceration & $\begin{array}{l}\text { Distal transection or parenchymal injury with duct injury } \\
\text { IV }\end{array}$ \\
Laceration & $\begin{array}{l}\text { Proximal } \\
\text { ampulla }\end{array}$ \\
\hline
\end{tabular}

*Advances one grade for multiple injuries up to grade II

${ }^{\text {a }}$ proximal pancreas is to the patients' right of the superior mesenteric vein 
Table 5 AAST organ injury scale for extrahepatic biliary tree injuries

Extrahepatic billiary tree injury scale

\begin{tabular}{ll} 
Grade* $^{*}$ & Description of injury \\
\hline I & Gallbladder contusion/hematoma \\
II & Portal triad contusion \\
& Partial gallbladder avulsion from liver bed; cystic duct intact \\
LII & Caceration or perforation of the gallbladder \\
& Complete gallbladder avulsion from liver bed \\
IV & Partial or complete right hepatic duct laceration \\
& Partial or complete left hepatic duct laceration \\
& Partial common hepatic duct laceration $(<50 \%)$ \\
& Partial common bile duct laceration $(<50 \%)$ \\
V & $>50 \%$ transection of common hepatic duct \\
& $>50 \%$ transection of common bile duct \\
& Combined right and left hepatic duct injuries \\
Intraduodenal or intrapancreatic bile duct injuries
\end{tabular}

*Advances one grade for multiple injuries up to grade III

- During surgical exploration of patients with abdominal trauma, the duodeno-pancreatic complex must be exposed and explored. (GoR 1A)

- During exploratory laparotomy, when biliary injury is suspected but not identified, an intraoperative cholangiogram is strongly recommended. (GoR $2 \mathrm{~A}$ )

- In patients who are clinically suspected of having duodenal-pancreatic injuries, and are deteriorating clinically, if the imaging is equivocal, a diagnostic laparotomy should be performed. (GoR 2A)

- In suspected pancreatic duct and extrahepatic biliary tree injuries in hemodynamically stable or stabilized adults and pediatric patients, the endoscopic retrograde cholangiopancreatography (ERCP) can be used for both diagnosis and treatment even in the early phase after trauma. (GoR 1B)

The diagnosis of duodeno-pancreatic injuries represents a challenge. In blunt trauma, evidence of direct impact on the upper abdomen such as lower rib fractures, soft tissue ecchymosis, supra-umbilical seat belt sign, and upper lumbar spine fractures following a motor vehicle collision should suggest the involvement of the pancreas and duodenum. Penetrating trauma of the front side or back side of both the lower torso or upper abdomen should be considered highly suspicious for duodeno-pancreatic or extrahepatic biliary tree lesions if the diagnoses have not been ruled out by other diagnostic means.
Clinical signs of traumatic DI are highly non-specific, especially in the early post-traumatic period. Patients usually present with epigastric, right upper quadrant, or back pain 6-24 h after the injury, but the onset of pain has been reported as late as 5 days after injury $[24,25]$. The most common test is the analysis of serum amylase and lipase [26]. However, in small-bowel injuries, initial amylase value does not differentiate between patients with perforated and non-perforated DI [27]. A normal amylase level does not exclude DI [28].

Persistently elevated or a rising level of amylase and lipase may be of prognostic significance for both pancreatic and duodenal injuries; therefore, measuring amylase and lipase levels every $6 \mathrm{~h}$ is recommended $[29,30]$. Accuracy may be improved if they are measured more than $3 \mathrm{~h}$ after injury [31, 32].

On E-FAST, the presence of free fluid in the absence of solid organ injury may be a sign of hollow viscus injury; however, it has limited role in diagnosing acute pancreatic or duodenal injuries [28, 33, 34].

Serum amylase levels are neither sensitive nor specific for definitive screening or diagnosis of PI, particularly within 3-6 h after injury. Serum lipase is more specific than amylase [35-37]; serum lipase may support targeted screening of patients with clinical suspicion of PI $[10,11,16,35,37-71]$.

Amylase is normal at admittance in up to $40 \%$ of patients with pancreatic trauma, and elevated levels are not 
Table 6 Duodeno-pancreatic and extra-hepatic biliary tree lesions

\begin{tabular}{|c|c|c|c|c|}
\hline Grade & WSES class & Organ & AAST & Description of injury \\
\hline \multirow[t]{3}{*}{ Minor } & \multirow[t]{3}{*}{ WSES class I } & Pancreas & $\mid-\|$ & $\begin{array}{l}\text { - Minor contusion without duct injury } \\
\text { Superficial laceration without duct injury } \\
\text { - Major contusion without duct injury or tissue loss } \\
\text { Major laceration without duct injury or tissue loss }\end{array}$ \\
\hline & & Duodenum & । & $\begin{array}{l}\text { - Hematoma involving a single portion of duodenum } \\
\text { Laceration: partial thickness, no perforation }\end{array}$ \\
\hline & & Extrahepatic biliary three & $|-||-|||$ & $\begin{array}{l}\text { - Gallbladder contusion/hematoma. Portal triad contusion } \\
\text { - Partial gallbladder avulsion from liver bed; cystic duct intact. } \\
\text { Laceration or perforation of the gallbladder } \\
\text { - Complete gallbladder avulsion from liver bed. Cystic duct laceration }\end{array}$ \\
\hline \multirow[t]{3}{*}{ Moderate } & \multirow[t]{3}{*}{ WSES class $\|$} & Pancreas & III & - Distal transection or parenchymal injury with duct injury \\
\hline & & Duodenum & $\|$ & $\begin{array}{l}\text { - Hematoma involving more than one portion } \\
\text { Laceration with disruption of less than } 50 \% \text { of circumference }\end{array}$ \\
\hline & & Extrahepatic biliary three & IV & $\begin{array}{l}\text { Partial or complete right hepatic duct laceration } \\
\text { Partial or complete left hepatic duct laceration } \\
\text { Partial common hepatic duct laceration }(<50 \%) \\
\text { Partial common bile duct laceration }(<50 \%)\end{array}$ \\
\hline \multirow[t]{4}{*}{ Severe } & \multirow[t]{3}{*}{ WSES class III } & Pancreas & IV-V & $\begin{array}{l}\text { - Proximal transection or parenchymal injury involving ampulla } \\
\text { - Massive disruption of pancreatic head }\end{array}$ \\
\hline & & Duodenum & ||$|-| V-V$ & $\begin{array}{l}\text { - Disruption } 50-75 \% \text { of circumference of D2 } \\
\text { Disruption } 50-100 \% \text { of circumference of D1, D3, and D4 } \\
\text { - Disruption > 75\% of circumference of D2 involving ampulla o } \\
\text { r distal common bile duct } \\
\text { - Massive disruption of duodeno-pancreatic complex } \\
\text { Devascularization of duodenum }\end{array}$ \\
\hline & & Extrahepatic biliary three & V & $\begin{array}{l}>50 \% \text { transection of common hepatic duct } \\
>50 \% \text { transection of common bile duct } \\
\text { Combined right and left hepatic duct injuries } \\
\text { Intraduodenal or intrapancreatic bile duct injuries }\end{array}$ \\
\hline & WSES class IV & Any & Any & Any degree of lesion with hemodynamic instability \\
\hline
\end{tabular}

specific for pancreatic trauma. Amylase can also be elevated in head, hepatic, and bowel injuries [61] and in alcohol abuse and after hypo-perfusion of the pancreas [26]. Lipase levels drawn on admission can be useful to exclude pancreatic injury but not to guide further investigation: negative predictive value (NPV) of normal lipase is $99.8 \%$, but with positive predictive value (PPV) of 3.3\% [36]. Amylase and lipase in association can reach sensitivity of $85 \%$ and specificity of $100 \%$, with PPV of $100 \%$ and NPV of 96\% (after $6 \mathrm{~h}$ from injury) [26, 69, 72]. Decreasing enzyme levels have been correlated with predicting success of NOM [16, 26, 35, 37, 40, 61, 70, 73]. Sensitivity of $88 \%$ and $96 \%$ NPV can be reached when amylase and lipase are associated to ultrasonography (US) [26, 36]. In lowresource settings, amylase and lipase, in combination with US, can be considered cost-effective methods to riskstratify patients [26]. Persistently, elevated serum amylase after 10 days from the initial injury should be monitored closely given the increased risk of pseudocyst formation in both adults and children [26, 40, 52, 63, 65, 70, 73-77].

Contrast-enhanced CT-scan is the fastest and most comprehensive technique for evaluating duodeno-pancreatic injuries [78-80]. In duodenal trauma, CT-scan has a sensitivity and specificity of $86 \%$ and $88 \%$, respectively, in diagnosing blunt hollow viscus injury [81-83]. However, missed blunt DI rates up to $27 \%$ have been described [84]. Of those with missed DI, 83\% had subtle CT findings on retrospective review [85]. Careful CT-scan interpretation with clinical correlation is mandatory to avoid delayed diagnosis and treatment with increased morbidity and mortality [28, 60, 61, 67, 79, 80, 82, 86-90]. In fact, isolated periduodenal fluid or hematoma visualized on admission abdominal CT-scan does not necessitate immediate exploration [83, 91-94]. Intraperitoneal or retroperitoneal extraluminal air is a relatively specific sign of bowel perforation seen in $20-55 \%$ of patients; however, it may not be visible immediately after a traumatic perforation [95].

In pancreatic trauma, contrast-enhanced CT-scan has high specificity (90-95\%) but low sensitivity (52-54\%) for ductal involvement. Up to $40 \%$ of PI can be missed or misdiagnosed on abdominal CT-scan obtained within 12 $\mathrm{h}$ of injury [96, 97]. PI becomes more evident 12-24 h after trauma [41, 67, 98]. A repeat CT-scan with curved multi-planar reconstruction and specific pancreatic phase (35-40 s from iodine contrast injection) can help in diagnosing pancreatic ductal (PD) injuries [61, 67, 82]. Aggressive resuscitation or prolonged hypovolemia can produce radiological changes in pancreatic imaging; fluid overload 


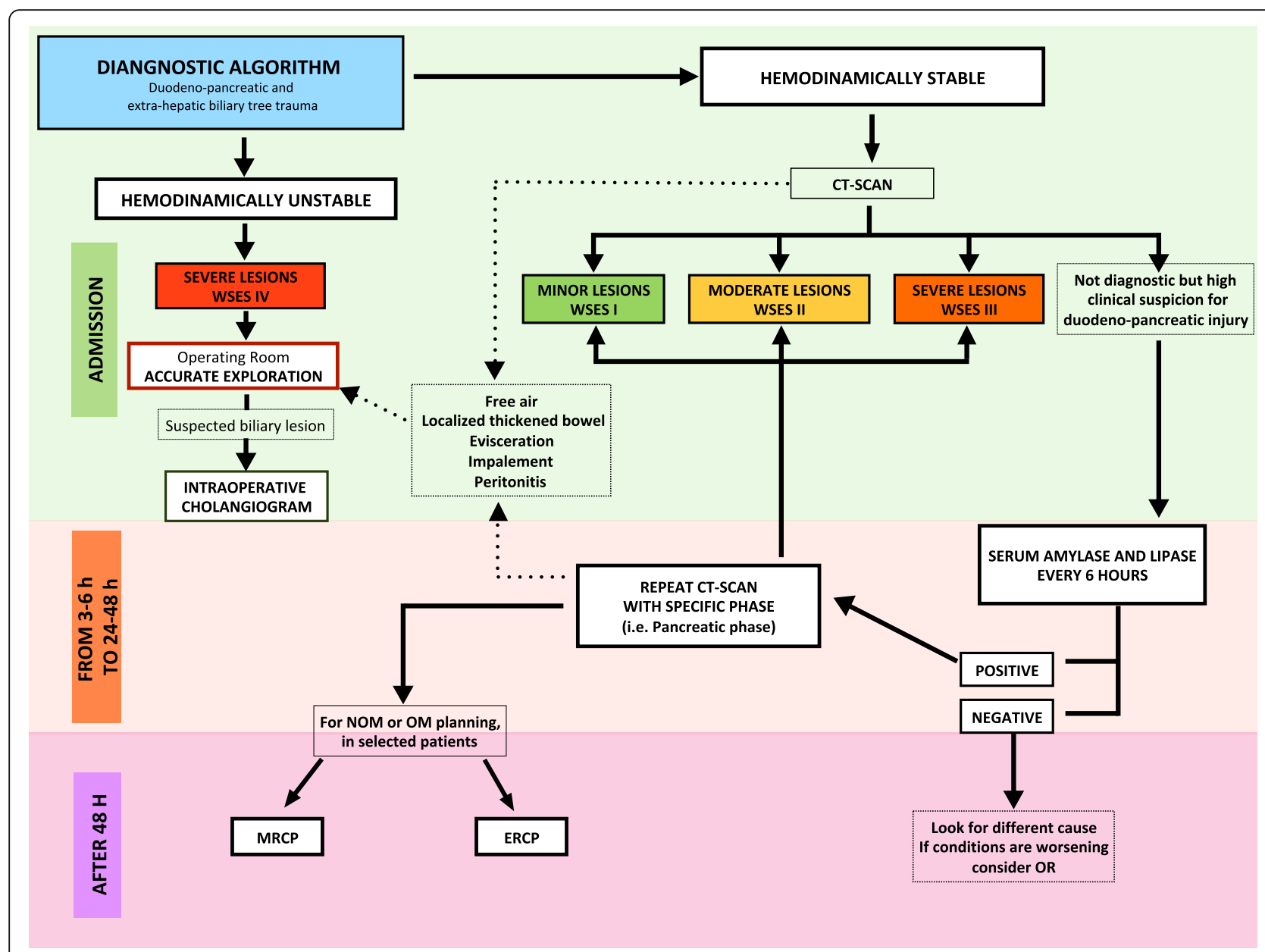

Fig. 2 Diagnostic algorithm for duodeno-pancreatic and extrahepatic biliary tree traumatic lesions

can induce peripancreatic edema or collections. In patients with severe shock both hypo- and hyper-perfusion of the gland have been described [99-101].

A repeat CT-scan 12-48 h after admission in doubtful cases of pancreatic-duodenal lesions should be considered $[91,102]$. The follow-up scan sensitivity for bowel perforation increases from 30 to $82 \%$ [103]. Moreover, the repeat CT-scan sensitivity for identification of an operative indication may increase up to $100 \%$ (67\%). NPV for OM also increases from 94 to $100 \%$ with no increase in mortality or hospital length of stay $[104,105]$. Complication rate is significantly higher only in those patients with delayed OM of more than $24 \mathrm{~h} \mathrm{[106].}$

The MRCP may be used in pancreatic-duodenal trauma to assess common bile duct/ampulla injury, and hepatobiliary contrast agents can help in localizing associated bile leaks. Minor injuries may be more evident on MRI than on CT-scan [79]. In association with secretin-dynamic study, the MRCP may diagnose pancreatic leakage $[107,108]$ and give additional information concerning parenchymal and proximal duct condition [71, 108, 109].
Oral contrast administration has not been shown to have substantial benefits in depicting bowel injuries when compared with CT-scan alone at the initial evaluation and during follow-up (sensitivity 95\%, specificity 99.6\%) [42, 102, 110-123].

Radiation-related risks in children and young patients must be considered. An increase in lifetime cancerspecific mortality of $801 / 4000(20.00025 \%)$ to $800 / 4000$ (20\%) after CT-scan has been reported for American children [124]. However, the consequences of missed injury or delay in diagnosis on mortality and morbidity rates can be grave particularly with duodeno-pancreatic injuries.

Plain films of the abdomen are generally of little value in diagnosing duodeno-pancreatic injuries [125]; the same is true for upper gastrointestinal series using water-soluble contrast. Duodenography (oral contrast-enhanced fluoroscopic evaluation) for blunt and penetrating duodenal trauma in patients with equivocal CT-scan has an overall sensitivity of $25 \%$ for blunt DI and 54\% for those requiring repair [126].

The ERCP may play a role in duodeno-pancreatic trauma in order to avoid late-diagnosis and/or treatment both in 


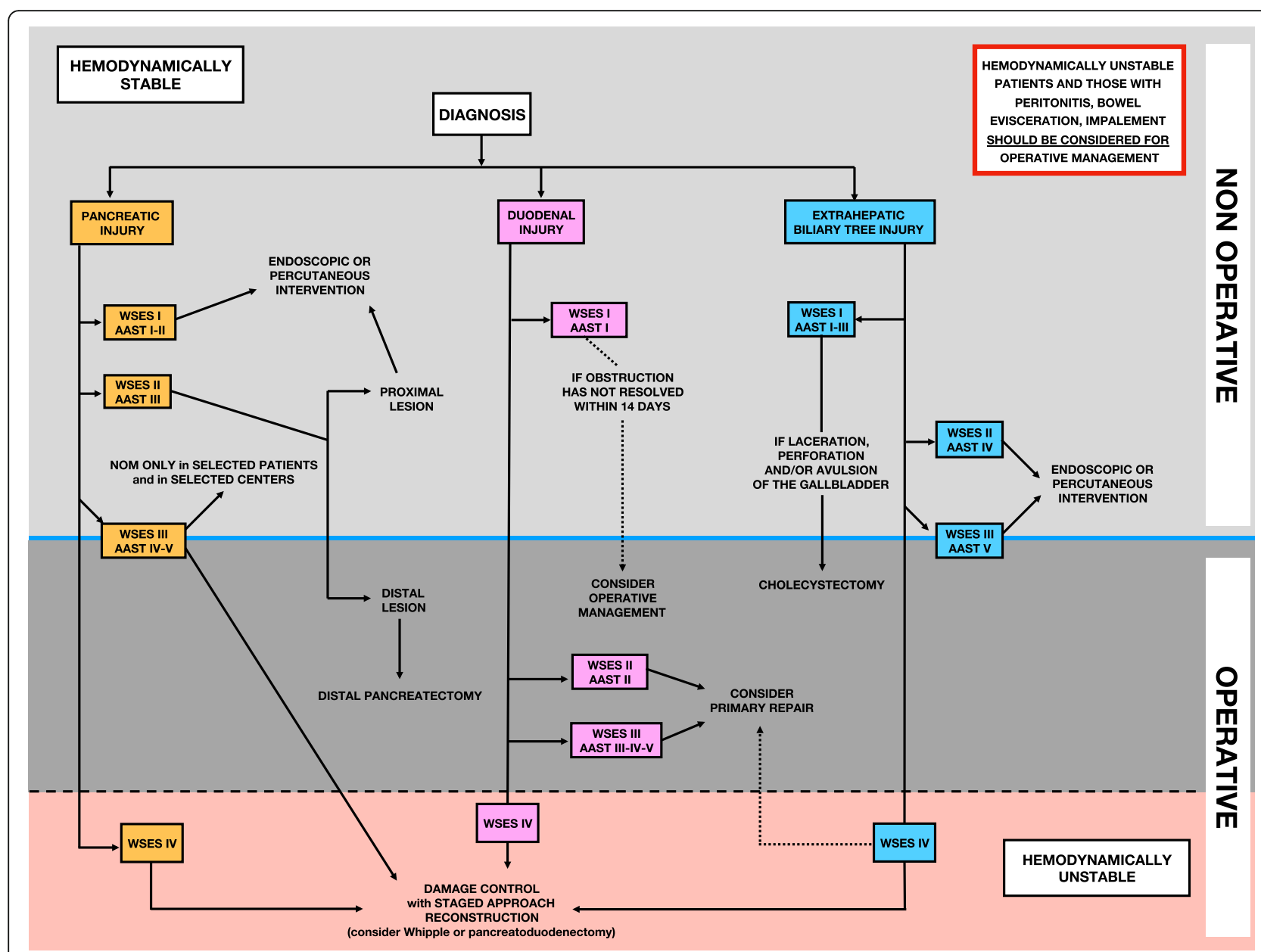

Fig. 3 Management algorithm for duodeno-pancreatic and extrahepatic biliary tree traumatic lesions (asterisk indicates NOM should only be attempted in centers capable of a precise diagnosis of the severity of PI/DI/EHBTI and capable of intensive management (close clinical observation and hemodynamic monitoring in a high dependency/intensive care environment, including serial clinical examination and laboratory assay, with immediate access to diagnostics, interventional radiology, endoscopy, and surgery and immediately available access to blood and blood products)

adult and pediatric patients $[10,15,41-43,48-52,58-60$, $62-64,67,68,70,76-78,90,97,101,127-149]$. It is an invasive procedure with $3-14 \%$ risk of post-procedure pancreatitis and $0.2-1 \%$ mortality rate $[6,10,11,40,41,45,49$, 51-53, 58, 61-64, 67, 68, 70-72, 75, 77, 78, 97, 128, 130, 133, 134, 137-140, 142, 144, 146, 148-157]. Moreover, in suspected duodenal perforations, the ERCP is not recommended. Failed cannulation of the papilla of Vater or inadequate pancreatography can occur in up to $9-14 \%$ of patients [71, 137, 144, 152]. The small duct size in children is not an absolute contraindication for the ERCP in expert hands as it is relatively safe and effective $[16,53,63,64,70$, $76,77,134,137,139,148,152,158]$. Rates of PD cannulation may be influenced by duodenal mucosal edema and/or hematomas and anatomical changes [71]. Despite of these limitations, the ERCP may have a role in decreasing time from definitive diagnosis of duct injury and first treatment in selected cases [131, 159]. However, cross-sectional imaging should be performed before proceeding with the ERCP.

Hepatobiliary scintigraphy (HIDA) is not frequently used in the initial work-up of the acute trauma patient due to long scan times and limited resource availability [128].

Percutaneous transhepatic cholangiogram (PTC) could be considered after non-feasible or unsuccessful ERCP for diagnosis and treatment [21].

Diagnostic peritoneal lavage (DPL) has sensitivity higher than $99 \%$ for hemoperitoneum but it is neither specific nor reliable for the assessment of retroperitoneal injuries, with undetected bowel perforation seen in up to $10 \%$ of cases [160-163]. DPL alone is associated with a high number of unnecessary laparotomies [164], with consequent shortand long-term complications. Moreover, DPL is associated with a $0.8-2.3 \%$ risk of specific complications $[165,166]$.

Diagnostic laparoscopy has both diagnostic and therapeutic potentials in a delayed setting. Whenever negative, 
it may reduce the number of unnecessary laparotomies [167]. It has a growing role in the evaluation of penetrating abdominal trauma but it has not been specifically studied for the evaluation of pancreatic-duodenal injuries. The duodeno-pancreatic anatomy and the retroperitoneal location increase the risk of missed injuries [168]. Moreover, laparoscopy in trauma requires adequate training and experience as well as sufficient staffing and equipment $[169,170]$.

Ultimately, in the patient with diagnostic uncertainty and in the patient with persistent or worsening clinical signs and symptoms, radiologic and/or laboratory alterations due to an intra-abdominal lesion, laparotomy should be strongly considered [171]. For penetrating trauma, a thorough and meticulous exploratory laparotomy with retroperitoneal exposure and assessment remains critical in detecting pancreatic and duodenal injuries [172].

If exploration is negative but there is still a strong suspicion of DI, methylene blue administration through a nasooro-gastric tube could be considered. During emergency laparotomy, the use of intraoperative pancreatography does not add to the visual findings [145]. Intraoperative cholangiogram through the cystic duct may help in defining EHBTI [87, 173]. Additional information can be provided by the use of intraoperative US of the pancreas; however, the lack of strong evidence and the necessity of trained surgeons make this technique not recommended or routinely used in trauma [130].

\section{Treatment}

\section{Non-operative management-duodenum}

- Hemodynamic stability is the key factor in determining management strategy. (GoR 1C)

- Hemodynamically unstable (WSES class IV) patients should not be considered for NOM. (GoR 1C)

- NOM can be considered for hemodynamically stable or stabilized patients with duodenal wall hematomas (WSES class I-II, AAST-OIS grade I-II) in absence of other abdominal organ injuries requiring surgery. (GoR 2B)

- Patients with progressive symptoms or worsening findings on repeat imaging should be considered failures of NOM. (GoR 2C)

- Hematomas initially treated with NOM should be considered for operative management if duodenal obstruction has not resolved within 14 days. (GoR 2C)

\section{Non-operative management-pancreatic and biliary tree}

- NOM should be the treatment of choice for all hemodynamically stable or stabilized minor PI WSES class I (AAST grade I and some grade II) and gallbladder hematomas without perforation WSES class I (AAST grade I) in the absence of other abdominal injuries requiring surgery. (GoR 2C)

- Location of WSES class II (AAST grade III) PI is the primary determinant of treatment modality in hemodynamically stable adult patients. (GoR 2C)

- NOM may be considered only in selected hemodynamically stable or stabilized patients with WSES class II (AAST grade III) very proximal pancreatic body injuries in the absence of other abdominal injuries requiring surgery and only in higher level trauma centers; success of NOM may be increased with utilization of endoscopic and percutaneous interventions. (GoR 2C)

- Optimal management of hemodynamically stable or stabilized patients with WSES class III (AAST grade IV) PI is controversial. NOM management augmented by endoscopic or percutaneous interventions may be used in selected patients. (GoR 2C)

- NOM of WSES class III (AAST grade IV) injuries should be considered only in an environment that provides around the clock capability for patient intensive monitoring, an immediately available endoscopy and interventional radiology suite, OR, and only in patients with stable or stabilized hemodynamic and absence of other abdominal injuries requiring surgery. (GoR 2A)

- Sequelae of PI such as pancreatic fistulae and pseudocysts can frequently be addressed with imageguided percutaneous drain placement, endoscopic stenting, internal drainage, and endoscopic cyst-gastrostomy or cyst-jejunostomy. (GoR 2C)

NOM is similar between adult and pediatric patients and is dependent on hemodynamic stability, clinical presentation, and associated injuries. Shock is generally due to associated injuries, which are present in 55$100 \%$ of pancreatic-duodenal injuries, and are more frequent among patients with penetrating mechanism of injury $[1,3,6,7,11,12,14,17,174-183]$.

Physical exam findings associated with DI are nonspecific and may be more reliable in children. Serial observations may increase the sensitivity of physical exam findings in diagnosing DI [57, 184]. CT-scan is generally the standard of care in diagnosing DI. Patients with definite evidence of full thickness laceration such as extravasation of enteral contrast or free air should undergo immediate operative intervention. These findings are rare, and in the vast majority of patients, findings are either non-specific such as duodenal wall thickening, periduodenal edema, stranding, or free fluid, or they are entirely absent $[62,84,91]$. NOM should include serial abdominal exams, bowel rest, and nasogastric tube 
(NGT) decompression. Parenteral nutrition may be required if obstruction persists beyond 7 days [185]. Obstruction due to duodenal hematoma will generally resolve within 14 days; if not, operative decompression may be required [185-188]. Operative evacuation can be done open or laparoscopically [188]. Percutaneous drainage of duodenal hematomas is a viable alternative [185, 189-193].

NOM of duodenal hematomas is generally successful in both adults and children [62, 91, 105, 185, 194]. Failed NOM (fNOM) rates between 5 and $10.3 \%$ have been reported, with no differences in length of stay. In patients with $\mathrm{fNOM}$, a $0-3 \%$ complication rate and reduced mortality compared with the group undergoing immediate OM has been reported $[91,105]$.

Minor PI is treated similarly in adults and children. Hemodynamically stable patients without associated operative injury should undergo a trial of NOM. Total parenteral nutrition (TPN) may be required in $62-73 \%$ of pediatric and $22.6 \%$ of adults $[8,12,15,16]$. NOM of class I injuries is successful in $96-100 \%$ of pediatric and $80-92.2 \%$ of adults $[6,11,15,105,195,196]$ and is associated with reduced morbidity, mortality, and shorter length of stay $[3,105]$.

In WSES class II (AAST-OIS grade III) injuries in hemodynamically stable or stabilized patients, location of the injury largely determines optimal treatment. WSES class II injuries distal to the superior mesenteric vein (AAST-OIS grade III) should be managed operatively by resection with or without splenectomy as OM is associated with improved recovery times, and reduced morbidity in both adults and pediatrics [197-199]. Isolated proximal WSES class II and III injuries (AASTOIS grade III and IV-V) may be considered for NOM. Although no randomized controlled trials exist, several large database studies and meta-analyses have demonstrated that NOM is pursued in $46 \%$ of pediatric and $28-48.5 \%$ of adult patients $[3,6,15]$.

NOM of WSES moderate and severe PI (AAST-OIS grade III and IV-V) has been reported more among pediatric than adult patients with a success rate up to $89 \%$ [15]. NOM success rate in adults is about $30 \%$. Pseudocyst rate was higher among NOM patients and in $65-74 \%$ of cases they were also managed non-operatively $[15,16]$. Length of stay was similar between NOM and OM $[9,200]$.

Endoscopic and percutaneous interventions such as ERCP with pancreatic stent and/or sphincterotomy or percutaneous aspiration and drain placement for pancreatic duct injury have been reported in patients with class II and III PI (AAST-OIS grades III and IV-V) with success rates of 6894\% with or without the octreotide administration [15, 201-208]. However, some concerns exist regarding increased rates of pancreatic duct stricture [209].

Many EHBTI will be diagnosed at the time of laparotomy. However, in patients undergoing NOM, concern for EHBTI should prompt immediate investigation with MRCP or HIDA scan. Patients with gallbladder wall hematoma without perforation can be managed expectantly [18]. NOM can be attempted in hemodynamically stable patients with WSES grade II and III injuries (AAST-OIS grade IV-V) without definite indication for surgical intervention. In these cases, fluid collections should be drained percutaneously and the ERCP with stent placement should be attempted to address ductal lacerations. Very little data exist about NOM of EHBTI but a few small case series have demonstrated success in both adult and pediatric patients $[18,19,21]$.

\section{Operative management-duodenum}

- Hemodynamically unstable (WSES class IV) patients and those with peritonitis or bowel evisceration or impalement should undergo immediate operative intervention. (GoR 1C)

- Damage control techniques should be considered in hemodynamically unstable patients with DI, particularly those with associated injuries and physiologic derangement. (GoR 2B)

- Primary repair of DI should be considered whenever technically possible regardless of grade of injury. (GoR 2B)

- Ancillary procedures such as pyloric exclusion with and without gastrojejunostomy and biliary diversion may be considered in WSES class III or higher DI (AAST grades III, IV, and V). (GoR 2C)

- Lesions requiring pancreaticoduodenectomy (Whipple procedure) are often accompanied by severe associated injuries and shock. Damage control techniques and staged reconstruction in subsequent phases performed by experienced surgeons should be considered. (GoR 2c)

\section{Operative management-pancreas and biliary tree}

- In WSES class I (AAST grade I and some grade II) PI found during exploratory laparotomy, drainage may be considered. (GoR 2B)

- Patients with distal WSES class II (AAST grade III) PI should undergo OM. (GoR 2C)

- Distal pancreatectomy (with or without splenectomy) is the procedure of choice for distal WSES class II (AAST grade III) PI. (GoR 2C)

- Pancreatoduodenectomy may be needed in patients with destructive injuries of the duodenal-pancreatic complex. In such cases, the operation has better results when performed in a staged fashion. Pancreato-jejunostomy or pancreato-gastrostomy reconstructions are equally effective in selected cases performed by experienced surgeons. (GoR 2C) 
- In extrahepatic biliary tree WSES class I injuries (AAST grades I, II, and III) with laceration, perforation, or avulsion of the gallbladder, cholecystectomy is the treatment of choice. (GoR 1C)

- EHBT injuries undergoing an initial damage control procedure may be drained with delayed reconstruction performed as a staged approach. (GoR 2B)

- EHBT WSES class II-III (AAST grades IV and V) injuries should undergo reconstruction with hepaticojejunostomy or choledochojejunostomy if there is no associated vascular injury. (GoR 2C)

- NOM failure of EHBT WSES class II-III (AAST grades IV and V) injuries, hepaticojejunostomy should be considered during reconstruction. (GoR 2C)

Due to the high percentage of associated injuries in patients with duodeno-pancreatic and extrahepatic biliary three injuries, shock and peritonitis are common at or shortly after presentation. Hemodynamic instability is present in $10-44 \%$ of patients [210-215]. All patients with hemodynamic instability or peritonitis should proceed immediately to OM. Hemodynamically stable patients with CT findings of full thickness laceration, or class III DI (AAST-OIS grade III-IV-V), such as free air or extravasation of enteral contrast from the duodenum or an associated operative injury should also undergo immediate OM.

Damage control surgery (DCS) is reported in 20-63\% of cases particularly in patients with associated vascular injuries and/or higher grade duodeno-pancreatic lesions. DCS has been associated with improved survival and equivalent or improved complication rates [2, 211, 212, $216,217]$. DCS is rarely needed for isolated DI, and the extent of the primary surgery will relate primarily to associated vascular injuries. Once hemostasis has been achieved, the DI can be addressed at the initial surgery if the patient's physiology allows. The majority of DI found at laparotomy are WSES class I-II lacerations (AASTOIS grade I-II). They should be repaired primarily in a tension-free transverse fashion after complete exposure and removal of all devitalized tissue. A nasogastric tube (NGT) should be placed to allow for proximal decompression. There is no evidence supporting routine periduodenal drain placement.

Management of WSES class III lacerations (AAST-OIS grade III-IV-V) not involving massive disruption of the duodeno-pancreatic complex is controversial. They are associated with a high mortality and high duodenal-specific morbidity (duodenal leak, fistula and anastomotic breakdown) with consequent abdominal sepsis and poor outcomes $[218,219]$. Duodenal diverticulization and triple tube decompression are no longer advocated for the treatment of DI [187, 218, 219]. Most modern studies advocate primary repair, NGT decompression, and external drain placement even with large, high-grade injuries. In cases where primary repair is not possible, segmental resection and primary duodeno-duodenostomy could be performed. These more conservative techniques have demonstrated good outcomes with similar or better mortality and duodenal-related morbidity compared with more complex drainage and reconstructive procedures [57, 181, 194, 211-213, 216, 217]. Pyloric exclusion (PE) is still utilized although definite indications for it remains controversial [220]. Temporary PE has been described both with and without gastrojejunostomy. The pylorus can be stapled without transection or sutured internally with absorbable material so it will open spontaneously several weeks postinjury [221, 222], or sutures can be removed endoscopically. Several studies reported no improvement in morbidity, mortality, and a prolonged length of stay with $\mathrm{PE}$ compared with primary repair with NGT decompression alone [212, 214, 215, 217, 223, 224]. Moreover, concerns exist regarding the possible PE increasing the length of the procedure, complications, and risks of gastric suture line and marginal ulcers [105, 222, 224-226].

WSES class III injuries with massive disruption of the duodeno-pancreatic complex (AAST-OIS grade III-IV$\mathrm{V}$ for duodenum and AAST-OIS grade IV-V for pancreas) are rare and require complex reconstruction. In the first or proximal second duodenal portion lesions where primary repair or resection and primary anastomosis are not possible, antrectomy and gastrojejunostomy with closure of the duodenum is an option [186]. In case of injuries located distal to the ampulla, a Rouxen-Y duodeno-jejunostomy can be performed [186, 187, 212]. When the ampulla or distal common bile duct is involved, re-implantation into healthy adjacent duodenum or reconstruction with a Roux-en-Y jejunal limb is an option if the adjacent tissue loss and injury are minimal [186]. When the duodenum and/or pancreatic head are severely devitalized or devascularized, pancreaticoduodenectomy (Whipple procedure) may be required. Associated injuries and severe physiologic derangements are common with these injuries [227-230]. DCS is required in $26-80 \%$ of cases and should be strongly considered at the time of initial operation [227-230]. It seems to improve survival and reduce complications in treating severe pancreatic-duodenal injuries requiring Whipple procedures [230]. Staged procedures have been suggested to improve outcomes. The assistance of experienced hepatobiliary surgeons should be defined on a case-by-case basis [187, 227-229]. Both classic Whipple procedures and pylorus preserving reconstructions are options dependent on the location of the DI and associated injuries [227, 231].

Delayed bowel function and obstruction from duodenal edema, hematoma, or stricture are common following DI 
[232]. To ensure adequate nutrition, a feeding jejunostomy may be considered in patients with severe duodenopancreatic injuries requiring resection and reconstruction; however, jejunostomy-related complications can occur in up to $7 \%$ of patients and intolerance to enteral nutrition is common [211, 232]. Total parenteral nutrition (TPN) may be required in $37-75 \%$ of patients $[57,185,213]$.

Patients with PI who are hemodynamically unstable (33-50\%) (WSES class IV) or have peritonitis should undergo immediate OM $[1,6,14,233]$. Associated hollow viscus injury or operative intra-abdominal injury will be present in $24-82 \%$ of PI $[4,5,11,233]$. DCS should be considered in patients with shock and exsanguinating hemorrhage. Surgical management of pancreatic injury is dependent on grade, location, and extent of associated injuries. Intraoperatively diagnosed WSES class I PI DCS (AAST-OIS grade I-II) can be managed expectantly, and closed suction drain placement is recommended for larger contusions and lacerations [234, 235]. Suture repair of lacerations should be avoided as it is associated with increased risk of pseudocyst formation [235]. WSES class II PI injuries (AAST-OIS grade III) involving the main pancreatic duct distal to the superior mesenteric vein (SMV) should be treated with distal pancreatectomy with or without splenectomy as $\mathrm{OM}$ is associated with improved recovery times, and reduced morbidity in both adult and pediatric PI [13, 197-199, 235]. Decreased incidence of pancreatic fistula when the pancreas was stapled rather than sewn has been demonstrated; however, ductal ligation made no difference [13]. Splenic preservation among trauma surgeons remains controversial. No significant increase in morbidity or mortality and a reduced length of stay associated with spleen preservation has been demonstrated [236]. Spleen preservation is of great importance in pediatric trauma patients; however, there is little data on splenic salvage in this cohort $[237,238]$. Ultimately, the decision to preserve or remove the spleen will depend on the patient's physiology, associated splenic injury, and the surgeon's level of experience.

Optimal management of WSES class III PI (AASTOIS grade IV-V) with transection of parenchyma/duct proximal to the SMV remains controversial. Subtotal and total pancreatectomy for proximal injuries may result in endocrine and exocrine dysfunction. Because of this, initial management includes debridement, oversewing the proximal pancreatic stump, and distal drainage with pancreaticojejunostomy (not well tolerated in physiologically deranged patients). These procedures are associated with high rates of pancreas-related (fistula) and overall complications. Modern studies predominantly utilize debridement and wide local drainage with good success $[2,4,14,239]$. Drainage alone for proximal PI has rates of pancreatic fistula of $12-13.8 \%$ [238, 240] which compares favorably with small series of more complex reconstructions with pancreaticoenterostomy $(11-20 \%)[241,242]$.

WSES class III PI (AAST-OIS grade IV-V) with complete destruction or devascularization of the pancreatic head and pancreatico-duodenal complex is a specific and rare circumstance. Most of these patients require pancreaticoduodenectomy and present in shock and with severe associated injuries and should be treated with DCS [243]. Mortality after trauma Whipple remains high varying from 12 to $33 \%$, but it may be improved with DCS techniques and appropriate patient selection [231, 244, 245]. Mortality with more conservative surgical treatments (duodenal reconstruction and drainage) appears to be similar, but complications, particularly pancreatic fistula, may be higher when compared with the Whipple procedure [13, 246].

Gallbladder WSES class I injuries (AAST-OIS grade III-III) account for approximately $30-60 \%$ of EHBTI [18-20]. The majority of these injuries are noted at the time of laparotomy. For all injuries except gallbladder wall hematomas, the treatment of choice is cholecystectomy $[18,19,22]$. Extrahepatic bile duct injuries often occur in conjunction with severe liver, duodenal, and pancreatic injuries. In these instances, management is dictated as much by the severity of the associated injuries as by the grade of the bile duct injury itself. In most cases, treatment of the injury with distal ligation and reconstruction with a Roux-en-Y hepaticojejunostomy is recommended $[18,19,21]$. Choledochojejunostomy may be used for distal common bile duct injuries in the absence of associated vascular injury that may compromise the blood supply to the anastomosis. Primary repair of WSES class II injuries (AAST-OIS grade IV) over a Ttube can be attempted but may result in strictures and need for future reconstructive surgery [18]. OM with Roux-en-Y hepaticojejunostomy is also recommended for patients with WSES class II and III injuries (AASTOIS grade IV-V) after fNOM $[18,21]$.

\section{Follow-up}

- After discharge, the necessity for follow-up imaging should be driven by clinical symptoms (i.e., onset of abdominal distention, tenderness, fever, vomiting, jaundice). (GoR 2B)

- In adults, CT-scan is usually the first-line follow-up imaging tool for new-onset signs and symptoms. (GoR 2A)

- In pregnant females, the MRCP should be considered the diagnostic modality of choice for new-onset signs and symptoms, wherever available. (GoR 2A)

- In pediatric patients, ultrasound or contrastenhanced US should be the diagnostic modality of 
choice for follow-up imaging. If cross-sectional imaging is required, MRI is preferred. (GoR 2A)

- Given the complexity and variability of traumatic injuries, the need for and choice of follow-up imaging should be made using a multidisciplinary approach. (GoR 2B)

CT-scan is usually the first-line imaging tool in the assessment of late complications of pancreatic trauma and very useful in driving management $[39,61,71,72,76,96,135$, $145,233,247,248]$. MRI is a reliable alternative to CT-scan in children and pregnant women [40, 45, 52, 97, 249, 250].

US or CEUS is used as an alternative to CT for followup of fluid collections, pseudocysts, and pancreatic disruptions after pancreatic trauma mainly in children or in low-resource settings $[16,26,40,45,49,53,55,63,71$, $75,78,133,134,138,245,247,251-254]$. CEUS may improve results of pancreatic imaging, being nearly as accurate as CT-scan and reducing radiation exposure in children [249, 255, 256].

The ERCP is a useful tool in diagnosis, management, and follow-up of late complications such as pseudocysts, pancreatic fistulas (i.e., trans-papillary stenting), or main duct strictures secondary to injury or prolonged stenting (i.e., ERCP with pancreatic duct dilatation and stenting), even in pediatric patients $[10,39,40,45,53,67,74,137$, $138,148,152,154,247,253]$.

NOM of high-grade pancreatic lesions (WSES class III, AAST-OIS grade IV-V) requires stringent follow-up for at least 6 months to detect early and late sequelae [45].

\section{Complications}

Pseudocyst is the most frequent complication following NOM [15, 52, 53, 64, 68, 69, 72, 154, 257, 258]. CT-scan is useful in evaluating pseudocysts and peripancreatic fluid collections following PI [96, 247, 259, 260] and in guiding percutaneous drainage [40]. US and endoscopic US (EUS) can also be used for follow-up and to guide percutaneous treatment of pseudocyst and abscess avoiding radiation exposure [45, 63, 70, 158, 247, 253]. Some authors propose combined EUS-ERCP procedures even in children [152, 158, 247]. The use of EUS in the work-up of children with pancreatobiliary pathology may limit exposure to risk of adverse events from ERCP [152]. MRCP and ERCP may be used-the first to document the communication of the cyst with the main pancreatic duct [40, $41,45,49,68,71,97,128,138,145,154,156,247,253$, $259,261]$ and, the latter, for treating the disease.

Abscess or intra-abdominal sepsis occurs in $7-25 \%$ of patients with pancreatic injuries; CT-scan or MRI should be performed for diagnosis and to guide treatment $[40,156]$.

Pancreatic fistula occurs in 10-35\% of major injuries of the pancreas after operative drainage or resection. A correct diagnosis is very important in planning the treatment. Preoperative cross-sectional imaging and pancreatogram during ERCP are essential. The ERCP, when feasible, is the first step to treat persisting fistulas [11, 40, 41, 48, 49, 61, 71, 156, 233, 262].

The incidence of post-traumatic pancreatitis is $17 \%$. Patients with abdominal pain and hyperamylasemia should undergo contrast-enhanced CT-scan for diagnosis wherever possible $[40,156]$.

Post-traumatic exocrine or endocrine function $\mathrm{Al}$ though transient post-operative glucose intolerance is common in all critically ill trauma patients, the incidence of persistent new-onset endocrine dysfunction after traumatic distal pancreatectomy is very low $(<4 \%)$ [263]; insulin requirement is more frequently associated to proximal pancreatic resections [72, 263] or Whipple procedure [264]. However, both exocrine and endocrine insufficiencies are very rare $[4,10,15,16,45,52,54,58$, $69,265]$ and no sufficient data exist to have definitive answers and indications [15, 68, 257]. Post-traumatic exocrine or endocrine function in the very long-term seems to be related to overall age and time from injury rather than the surgical treatment $[68,69]$. Long-term follow-up is suggested for patients who underwent pancreatic surgery for trauma due to the possibility that the onset of diabetes mellitus may be accelerated by pancreatic resection [53, 264].

\section{Conclusions}

Non-operative management of bilio-duodeno-pancreatic injuries without ductal involvement with or without endoscopic adjuncts is recommended for hemodynamically stable patients. EHBTI can be managed with cholecystectomy for minor injuries, although more severe injuries require surgical reconstruction. Severe bilio-duodenopancreatic injuries are rare, often accompanied by hemodynamic instability and may benefit from DCS techniques. Many initial injuries as well as the sequelae of injury may be addressed with percutaneous or endoscopic drainage, and endoscopic stenting. Despite advances in care, morbidity and mortality following severe bilio-duodeno-pancreatic trauma remain high. The management of duodenal, pancreatic, and extrahepatic biliary tree injuries must be multidisciplinary. The management in the initial phase is best accomplished by the trauma or emergency surgeon, and in the reconstructive phase, hepatobiliary surgeons may be helpful and should be consulted.

\footnotetext{
Abbreviations

AAST: American Association for the Surgery for Trauma; BE: Base excess; $C T$ : Computerized tomography; DCS: Damage control surgery; DI: Duodenal injury; DPL: Diagnostic peritoneal lavage; E-FAST: Extended-Focused Assessment with Sonography for Trauma; EHBTI: Extrahepatic biliary tree injury; ERCP: Endoscopic retrograde cholangiopancreatography; EUS: Endoscopic US; fNOM: Failed non-operative management;
} 
HIDA: Hepatobiliary scintigraphy; LE: Level of evidence; MRCP: Magnetic resonance cholangiopancreatography; MRI: Magnetic resonance imaging; NGT: Nasogastric tube; NOM: Non-operative management; NPV: Negative predicting value; OIS: Organ injury scale; OM: Operative management: PD: Pancreatic duct; PE: Pyloric exclusion; PI: Pancreatic injury; PPV: Positive predicting value; PTC: Percutaneous transhepatic cholangiogram; SMV: Superior mesenteric vein; TPN: Total parenteral nutrition; US: Ultrasound; WSES: World Society of Emergency Surgery

\section{Acknowledgements \\ None \\ Contributors: \\ WSES-AAST Expert Pane}

Offir Ben-Ishay (1), Matti Tolonen (2), Riccardo Bertelli (3), Tal Horer (4), Paula Ferrada (5), Isidoro Di Carlo (6), Bruno M Pereira (7), Dario Parini (8), Giulia Montori (9), Belinda De Simone (10), Osvaldo Chiara (11), Andreas Hecker (12), Nicola DeAngelis (13), Carlos Augusto Gomes (14), Joseph Galante (15), Miklosh Bala (16), Konstantinos S Mylonas (17), Anastasia Pikoulis (18), Paola Perfetti (19), Mircea Chirica (20), Joaquin Bado (21), Kenji Inaba (22), Neil Parry (23), Oreste Romeo (24), Martijn Stommel (25), Mohan Rajashekar (26), Edward Tan (27), Francesco Salvetti (28), Boris Sakakushev (29)

(1) General and Trauma Surgery, Rambam Medical Centre, Tel Aviv, Israel (2) General Surgery Dept., Mehilati Hospital, Helsinki, Finland

(3) General Emergency and Trauma Surgery, Bufalini Hospital, Cesena, Italy (4) Dept. of Cardiothoracic and Vascular Surgery \& Dept. of Surgery Örebro University Hospital and Örebro University, Sweden

(5) General and Trauma Surgery, Virginia Commonwealth University, Richmond, Virginia, USA

(6) Department of Surgical Sciences and Advanced Technologies "GF Ingrassia", University of Catania, Cannizzaro Hospital, Catania, Italy (7) Trauma/Acute Care Surgery \& Surgical Critical Care, University of Campinas, Campinas, Brazil

(8) General Surgery Dept., Rovigo Hospital, Rovigo, Italy

(9) General Surgery Dept., Aviano Hospital, Aviano, Italy

(10) General Surgery Dept., Guastalla Hospital, Guastalla, Italy

(11) Emergency and Trauma Surgery Dept., Niguarda Hospital, Milano, Italy

(12) Department of General and Thoracic Surgery, University Hospital of Giessen, Giessen, Germany.

(13) Unit of Digestive Surgery, HPB Surgery and Liver Transplant, Henri Mondor Hospital, Créteil, France

(14) Hospital Universitário Terezinha De Jesus, Faculdade De Ciências Médicas E Da Saúde De Juiz De Fora (Suprema) Brazil

(15) Trauma and Acute Care Surgery and Surgical Critical Care Trauma, Department of Surgery University of California, Davis, USA

(16) General Surgery Dept., Hadassah Medical Centre, Jerusalem, Israel

(17) 3rd Department of Surgery, Attiko Hospital, National \& Kapodistrian University of Athens, Greece

(18) General Surgery, Medical School, NKUA, Athen, Greece

(19) Emergency Medicine Dept., Verona Hospital, Verona, Italy

(20) Chirurgie Digestive, CHUGA-CHU Grenoble Alpes, Grenoble, France

(21) General and Emergency Surgery Dept., Montevideo Hospital,

Montevideo, Paraguay

(22) Division of Trauma \& Critical Care, LAC+USC Medical Center, Los

Angeles, CA, USA

(23) General and Trauma Surgery Dept., London Health Sciences Centre, Victoria Hospital, London, ON, Canada

(24) Trauma and Surgical Critical Care, University of Michigan Health System, East Medical Center Drive, Ann Arbor, MI, USA

(25) Department of Surgery, Radboud University Medical Center, Nijmegen, The Netherlands.

(26) General Surgery, Hegde Hospital, Mangaluru, Karnataka, India

(27) Emergency Med. Dept., Radboud University Medical Center, Nijmegen,

The Netherlands.

(28) General Surgery, Pavia University Hospital, Pavia, Italy

(29) General Surgery Department, Medical University, University Hospital St

George, Plovdiv, Bulgaria.

\section{Authors' contributions}

FC, LK, YK, EEM, LA, WB, AL, GA, VR, IW, AK, FAZ, EC, GPF, CO, EP, MGS, RM, YM, PTM, VK, ACM, RI, FF, VM, MS, FM, JM, MC, CA, FC, and RC contributed in the conception and drafting of the manuscript, critically revised the manuscript, and contributed with important scientific knowledge giving the final approval.

\section{Funding}

None

\section{Availability of data and materials}

Not applicable

\section{Ethics approval and consent to participate}

Not applicable

\section{Consent for publication}

Not applicable

\section{Competing interests}

The authors declare that they have no competing interests.

\section{Author details}

${ }^{1}$ General, Emergency and Trauma Surgery Department, Pisa University Hospital, Via Paradisa, 2, 56124 Pisa, Italy. '2Division of Trauma, Surgical Critical Care, Burns and Acute Care Surgery, University of California San Diego, San Diego, USA. ${ }^{3}$ Division of General Surgery, Rambam Health Care Campus, Haifa, Israel. ${ }^{4}$ Trauma Surgery, Denver Health, Denver, CO, USA. ${ }^{5}$ General, Emergency and Trauma Surgery Department, Bufalini Hospital, Cesena, Italy. ${ }^{6}$ Trauma Surgery Department, Scripps Memorial Hospital, La Jolla, CA, USA. ${ }^{7}$ General Surgery Department, Mehilati Hospital, Helsinki, Finland. ${ }^{8}$ Department of Surgery, Zagreb University Hospital Centre and School of Medicine, University of Zagreb, Zagreb, Croatia. ${ }^{9}$ General and Emergency Surgery, Sergei Kirov Military Academy, Saint Petersburg, Russia.

${ }^{10}$ Department of Surgery, DHS Hospitals, Srinagar, Kashmir, India. ${ }^{11}$ General, Acute Care, Abdominal Wall Reconstruction, and Trauma Surgery, Foothills Medical Centre, Calgary, Alberta, Canada. ${ }^{12}$ Department of Surgery, College of Medicine and Health Sciences, UAE University, Al-Ain, United Arab Emirates. ${ }^{13}$ Trauma/Acute Care Surgery \& Surgical Critical Care, University of Campinas, Campinas, Brazil. ${ }^{14}$ Trauma and Acute Care Surgery, Fundacion Valle del Lili, Cali, Colombia. ${ }^{15} 3$ rd Department of Surgery, Attiko Hospital, National \& Kapodistrian University of Athens, Athens, Greece. ${ }^{16}$ Department of Surgery, Harborview Medical Centre, Seattle, USA. ${ }^{17}$ Department of Emergency and Critical Care Medicine, Chiba University Hospital, Chiba, Japan. ${ }^{18}$ Pediatric Trauma Service, Massachusetts General Hospital, Boston, MA, USA. ${ }^{19}$ General Surgery Department, Mozir City Hospital, Mazyr, Belarus. ${ }^{20}$ Department of Surgery and Obstetrics and Gynecology, University of Buea, Buea, Cameroon. ${ }^{21}$ General and Trauma Surgery, Virginia Commonwealth University, Richmond, VA, USA. ${ }^{22}$ General and Trauma Surgery Department, Pietermaritzburg Hospital, Pietermaritzburg, South Africa. ${ }^{23}$ General and Emergency Surgery, Macerata Hospital, Macerata, Italy. ${ }^{24}$ General and Emergency Surgery Department, Montevideo Hospital, Montevideo, Uruguay. ${ }^{25}$ Department of Emergency and Critical Care Medicine, Saint-Marianna University School of Medicine, Kawasaki, Japan. ${ }^{26} \mathrm{Clin}$. Univ. de Chirurgie Digestive et de I'Urgence, CHUGA-CHU Grenoble Alpes, UGA-Université Grenoble Alpes, Grenoble, France. ${ }^{27}$ Emergency and Trauma Surgery, Maggiore Hospital, Parma, Italy. ${ }^{28}$ Department of General Surgery, Riverside University Health System Medical Center, Moreno Valley, CA, USA.

\section{Received: 7 November 2019 Accepted: 18 November 2019}

\section{Published online: 11 December 2019}

\section{References}

1. Vasquez JC, Coimbra R, Hoyt DB, Fortlage D. Management of penetrating pancreatic trauma: an 11-year experience of a level-1 trauma center. Injury. 2001:32:753-9.

2. Rickard MJFX, Brohi K, Bautz PC. Pancreatic and duodenal injuries: keep it simple. ANZ J Surg. 2005;75:581-6.

3. Siboni S, Kwon E, Benjamin E, Inaba K, Demetriades D. Isolated blunt pancreatic trauma: a benign injury? J Trauma Acute Care Surg. 2016; 81:855-9.

4. Vertrees A, Elster E, Jindal R, Ricordi C, Shriver C. Surgical management of modern combat-related pancreatic injuries: traditional management and unique strategies. Mil Med. 2014;179:315-9. 
5. Kantharia CV, Prabhu RY, Dalvi AN, Raut A, Bapat RD, Supe AN. Spectrum and outcome of pancreatic trauma. Trop Gastroenterol. 2007;28:105-8.

6. Menahem B, Lim C, Lahat E, Salloum C, Osseis M, Lacaze L, et al. Conservative and surgical management of pancreatic trauma in adult patients. Hepatobiliary Surg Nutr. 2016;5:470-7.

7. Pata G, Casella C, Di Betta E, Grazioli L, Salerni B. Extension of nonoperative management of blunt pancreatic trauma to include grade III injuries: a safety analysis. World J Surg. 2009;33:1611-7.

8. Houben CH, Ade-Ajayi N, Patel S, Kane P, Karani J, Devlin J, et al. Traumatic pancreatic duct injury in children: minimally invasive approach to management. J Pediatr Surg. 2007;42:629-35.

9. Englum BR, Gulack BC, Rice HE, Scarborough JE, Adibe OO. Management of blunt pancreatic trauma in children: review of the National Trauma Data Bank. J Pediatr Surg. 2016;51:1526-31.

10. Kaman L, lqbal J, Pall M, Bhukal I, Behera A, Singh G, et al. Current management of pancreatic trauma. Trop Gastroenterol. 2012;33:200-6.

11. Girard E, Abba J, Arvieux C, Trilling B, Sage PY, Mougin N, et al. Management of pancreatic trauma. J Visc Surg. 2016;153:259-68.

12. Addison P, lurcotta T, Amodu LI, Crandall G, Akerman M, Galvin D, et al. Outcomes following operative vs. non-operative management of blunt traumatic pancreatic injuries: a retrospective multi-institutional study. Burn Trauma. 2016:4:39.

13. Byrge N, Heilburn M, Winkler N, Sommers D, Evans H, Cattin LM, et al. An AAST-MITC analysis of pancreatic trauma: staple or sew? Resect or drain? J Trauma Acute Care Surg. 2018:85:1.

14. Antonacci N, Di Saverio S, Ciaroni V, Biscardi A, Giugni A, Cancellieri F, et al. Prognosis and treatment of pancreaticoduodenal traumatic injuries: which factors are predictors of outcome? J Hepatobiliary Pancreat Sci. 2011;18: 195-201.

15. Koh EY, van Poll D, Goslings JC, Busch OR, Rauws EA, Oomen MW, et al. Operative versus nonoperative management of blunt pancreatic trauma in children. Pancreas. 2017:46:1091-7.

16. Naik-Mathuria BJ, Rosenfeld EH, Gosain A, Burd R, Falcone RA, Thakkar R, et al. Proposed clinical pathway for nonoperative management of highgrade pediatric pancreatic injuries based on a multicenter analysis: a pediatric trauma society collaborative. J Trauma Acute Care Surg. 2017;83: 589-96

17. Young PR, Meredith JW, Baker CC, Thomason MH, Chang MC. Pancreatic injuries resulting from penetrating trauma: a multi-institution review. Am Surg. 1998;64:838-43 discussion 843-4.

18. Thomson BNJ, Nardino B, Gumm K, Robertson AJ, Knowles BP, Collier NA, et al. Management of blunt and penetrating biliary tract trauma. J Trauma Acute Care Surg. 2012;72:1620-5.

19. Sawaya DE, Johnson LW, Sittig K, McDonald JC, Zibari GB. latrogenic and noniatrogenic extrahepatic biliary tract injuries: a multi-institutional review. Am Surg. 2001;67:473-7.

20. Jurkovich GJ, Hoyt DB, Moore FA, Ney AL, Morris JA, Scalea TM, et al. Portal triad injuries. J Trauma. 1995;39:426-34.

21. Soukup ES, Russell KW, Metzger R, Scaife ER, Barnhart DC, Rollins MD. Treatment and outcome of traumatic biliary injuries in children. J Pediatr Surg. 2014;49:345-8

22. Ball CG, Dixon E, Kirkpatrick AW, Sutherland FR, Laupland KB, Feliciano DV. A decade of experience with injuries to the gallbladder. J Trauma Manag Outcomes. 2010;4:3.

23. Oxford Centre for Evidence-based Medicine - Levels of Evidence (March 2009) - CEBM. Available from: http://www.cebm.net/oxford-centre-evidencebased-medicine-levels-evidence-march-2009/. Accessed June 2019.

24. Schneider R, Moebius C, Thelen A, Jonas S. Duodenal perforation after abdominal trauma. Zentralbl Chir. 2009;134:567-9.

25. Jain S, Telang P, Joshi MA, Prabhakar S. Isolated pancreatic injury following blunt abdominal trauma in a child. Indian J Crit Care Med. 2007;11:96-8.

26. Mahajan A, Kadavigere R, Sripathi S, Rodrigues GS, Rao VR, Koteshwar P. Utility of serum pancreatic enzyme levels in diagnosing blunt trauma to the pancreas: a prospective study with systematic review. Injury. 2014;45:1384-93.

27. Fakhry SM, Watts DD, Luchette FA, EAST Multi-Institutional Hollow Viscus Injury Research Group. Current diagnostic approaches lack sensitivity in the diagnosis of perforated blunt small bowel injury: analysis from 275,557 trauma admissions from the EAST Multi-Institutional HVI Trial. J Trauma Inj Infect Crit Care. 2003;54:295-306.

28. Jurkovich G. The duodenum and pancreas. In: Mattox KL, Feliciano DV Moore EE, editors. Trauma. 4th ed. New York: McGraw-Hill; 2000. p. 735-62.
29. Asensio JA, Forno W. Pancreatic injuries. In: Demetriades D, Asensio JA, editors. Trauma Handb. Georgetown: Landes Biosciences Co; 2000. p. 346-53.

30. Asensio JA, Forno W. Duodenal injuries. In: Demetriades D, Asensio JA, editors. Trauma Handb. Georgetown: Landes Biosciences Co; 2000. p. 354-60.

31. Takishima T, Sugimoto K, Hirata M, Asari Y, Ohwada T, Kakita A. Serum amylase level on admission in the diagnosis of blunt injury to the pancreas: its significance and limitations. Ann Surg. 1997;226:70-6.

32. Odom SR, Howell MD, Silva GS, Nielsen VM, Gupta A, Shapiro NI, et al. Lactate clearance as a predictor of mortality in trauma patients. J Trauma Acute Care Surg. 2013;74:999-1004.

33. Körner M, Krötz MM, Degenhart C, Pfeifer K-J, Reiser MF, Linsenmaier U. Current role of emergency us in patients with major trauma. Radiographics. 2008:28:225-42.

34. Kunin JR, Korobkin M, Ellis JH, Francis IR, Kane NM, Siegel SE. Duodenal injuries caused by blunt abdominal trauma: value of CT in differentiating perforation from hematoma. AJR Am J Roentgenol. 1993;160:1221-3.

35. Rau C-S, Wu S-C, Chien P-C, Kuo P-J, Chen Y-C, Hsieh H-Y, et al. Identification of pancreatic injury in patients with elevated amylase or lipase level using a decision tree classifier: a cross-sectional retrospective analysis in a level I trauma center. Int J Environ Res Public Health. 2018;15:277.

36. Mitra B, Fitzgerald M, Raoofi M, Tan GA, Spencer JC, Atkin C. Serum lipase for assessment of pancreatic trauma. Eur J Trauma Emerg Surg. 2014;40: 309-13.

37. Yu DTY, Ngo TL, Goldstein M. Child abuse-a review of inflicted intraoral, esophageal, and abdominal visceral injuries. Clin Pediatr Emerg Med. 2016; 17:284-95.

38. Gupta A, Kumar S, Yadav SK, Mishra B, Singhal M, Kumar A, et al. Magnitude, severity, and outcome of traumatic pancreatic injury at a level I trauma center in India. Indian J Surg. 2017;79:515-20.

39. Girard E, Abba J, Cristiano N, Siebert M, Barbois S, Létoublon C, et al. Management of splenic and pancreatic trauma. J Visc Surg. 2016;153:45-60.

40. Kumar A, Panda A, Gamanagatti S. Blunt pancreatic trauma: a persistent diagnostic conundrum? World J Radiol. 2016;8:159-73.

41. Potoka DA, Gaines BA, Leppäniemi A, Peitzman AB. Management of blunt pancreatic trauma: what's new? Eur J Trauma Emerg Surg. 2015;41:239-50.

42. Daly KP, Ho CP, Persson DL, Gay SB. Traumatic retroperitoneal injuries: review of multidetector CT findings. Radiographics. 2008;28:1571-90.

43. Lynch T, Kilgar J, Al SA. Pediatric abdominal trauma. Curr Pediatr Rev. 2018; 14:59-63.

44. Fisher RM. Paediatric trauma. Surgery. 2015;33:437-41.

45. Hiremath $B$, Hegde N. Non-operative management of a grade IV pancreatic injury. BMJ Case Rep. 2014;2014:bcr2014203805.

46. Intravia JM, DeBerardino TM. Evaluation of blunt abdominal trauma. Clin Sports Med. 2013;32:211-8.

47. Memon AA, Zafar H, Raza R, Murtaza G. Traumatic pancreatic injury--an elusive diagnosis: experience from a developing country urban trauma referral centre. J Pak Med Assoc. 2013:63:440-4.

48. Lahiri R, Bhattacharya S. Pancreatic trauma. Ann R Coll Surg Engl. 2013; 95:241-5

49. Debi U, Kaur R, Prasad KK, Sinha SK, Sinha A, Singh K. Pancreatic trauma: a concise review. World J Gastroenterol. 2013;19:9003-11.

50. Rosenfeld EH, Vogel A, Russell RT, Maizlin I, Klinkner DB, Polites S, et al. Comparison of diagnostic imaging modalities for the evaluation of pancreatic duct injury in children: a multi-institutional analysis from the Pancreatic Trauma Study Group. Pediatr Surg Int. 2018;34:961-6.

51. Kohler JE, Chokshi NK. Management of abdominal solid organ injury after blunt trauma. Pediatr Ann. 2016:45:e241-6.

52. Haugaard MV, Wettergren A, Hillings $\varnothing$ JG, Gluud C, Penninga L. Nonoperative versus operative treatment for blunt pancreatic trauma in children. Cochrane Database Syst Rev. 2014;(2):CD009746.

53. Westgarth-Taylor C, Loveland J. Paediatric pancreatic trauma: a review of the literature and results of a multicentre survey on patient management. $\mathrm{S}$ Afr Med J. 2014;104:803-7.

54. Onder A, Kapan M, Tekbas G, Arikanoglu Z, Aliosmanoglu I, Taskesen F, et al Blunt trauma - related isolated pancreatic injury. Bratisl Lek Listy. 2013;114: 519-22.

55. Xie K-L, Liu J, Pan G, Hu W-M, Wan M-H, Tang W-F, et al. Pancreatic injuries in earthquake victims: what have we learnt? Pancreatology. 2013;13:605-9.

56. Maguire SA, Upadhyaya M, Evans A, Mann MK, Haroon MM, Tempest V, et al. A systematic review of abusive visceral injuries in childhood--their range and recognition. Child Abuse Negl. 2013;37:430-45. 
57. Gutierrez IM, Mooney DP. Operative blunt duodenal injury in children: a multi-institutional review. J Pediatr Surg. 2012;47:1833-6.

58. Al-Ahmadi K, Ahmed N. Outcomes after pancreatic trauma: experience at a single institution. Can J Surg. 2008;51:118-24.

59. Yang $L$, Zhang $X M, X U X X$, Tang $W$, Xiao B, Zeng NL. MR imaging for blunt pancreatic injury. Eur J Radiol. 2010;75:e97-101.

60. Gordon RW, Anderson SW, Ozonoff A, Rekhi S, Soto JA. Blunt pancreatic trauma: evaluation with MDCT technology. Emerg Radiol. 2013;20:259-66.

61. Linsenmaier $\mathrm{U}$, Wirth $\mathrm{S}$, Reiser M, Körner M. Diagnosis and classification of pancreatic and duodenal injuries in emergency radiology. Radiographics. 2008;28:1591-602.

62. Spaniolas K, Velmahos GC. Nonoperative management of pancreatoduodenal injuries. Eur J Trauma Emerg Surg. 2007;33:221.

63. Bosboom D, Braam AWE, Blickman JG, Wijnen RMH. The role of imaging studies in pancreatic injury due to blunt abdominal trauma in children. Eur J Radiol. 2006;59:3-7.

64. Cuenca AG, Islam S. Pediatric pancreatic trauma: trending toward nonoperative management? Am Surg. 2012;78:1204-10.

65. Herman R, Guire KE, Burd RS, Mooney DP, Ehlrich PF. Utility of amylase and lipase as predictors of grade of injury or outcomes in pediatric patients with pancreatic trauma. J Pediatr Surg. 2011;46:923-6.

66. Fenton SJ, Peterson DN, Connors RC, Hansen KW, Metzger RR, Scaife ER. A Standard pediatric trauma laboratory panel: a plea for a minimalist approach. J Trauma Inj Infect Crit Care. 2009;66:703-6.

67. Stewart BT, Sandstrom CK, O'Keefe G, Balmadrid B, Johnson GE. Multidisciplinary diagnosis and management of pancreatic trauma. Dig Dis Interv. 2018;02:179-92.

68. Søreide K, Weiser TG, Parks RW. Clinical update on management of pancreatic trauma. HPB. 2018;20:1099-108.

69. Iurcotta T, Addison P, Amodu LI, Fatakhova K, Akerman M, Galvin D, et al. Patterns and outcomes of traumatic pancreatic injuries: a retrospective review from a large multi-institutional healthcare system. Trauma. 2018;20: 11-29 SAGE PublicationsSage UK: London, England.

70. Kollár D, Molnár TF, Zsoldos P, Benedek-Tóth Z, Oláh A. Diagnosis and management of blunt pancreatic trauma. Surg Gastroenterol Oncol. 2018;23:23-25.

71. Krige J, Jonas E, Thomson S, Beningfield S. The management of pancreatic injuries. Trauma. 2017;19:243-53 SAGE PublicationsSage UK: London, England.

72. Johnsen NV, Betzold RD, Guillamondegui OD, Dennis BM, Stassen NA, Bhullar I, et al. Surgical management of solid organ injuries. Surg Clin North Am. 2017:97:1077-105.

73. Aydogdu B, Arslan S, Zeytun H, Arslan MS, Basuguy E, Içer M, et al. Predicting pseudocyst formation following pancreatic trauma in pediatric patients. Pediatr Surg Int. 2016:32:559-63.

74. Thomson DA, Krige JEJ, Thomson SR, Bornman PC. The role of endoscopic retrograde pancreatography in pancreatic trauma: a critical appraisal of 48 patients treated at a tertiary institution. J Trauma Acute Care Surg. 2014;76:1362-6.

75. lacono C, Zicari M, Conci S, Valdegamberi A, De Angelis M, Pedrazzani C, et al. Management of pancreatic trauma: a pancreatic surgeon's point of view. Pancreatology. 2016;16:302-8.

76. Dai L-N, Chen C-D, Lin X-K, Wang Y-B, Xia L-G, Liu P, et al. Abdominal injuries involving bicycle handlebars in 219 children: results of 8-year followup. Eur J Trauma Emerg Surg. 2015;41:551-5 Springer Berlin Heidelberg.

77. Lesher A, Williams R. Pancreatic and duodenal trauma in children. J Pediatr Intensive Care. 2015:4:21-6.

78. Melamud K, LeBedis CA, Soto JA. Imaging of pancreatic and duodenal trauma. Radiol Clin North Am. 2015;53:757-71.

79. laselli F, Mazzei MA, Firetto C, D'Elia D, Squitieri NC, Biondetti PR, et al. Bowel and mesenteric injuries from blunt abdominal trauma: a review. Radiol Med. 2015;120:21-32.

80. Cinquantini F, Tugnoli G, Piccinini A, Coniglio C, Mannone S, Biscardi A, et al. Educational review of predictive value and findings of computed tomography scan in diagnosing bowel and mesenteric injuries after blunt trauma: correlation with trauma surgery findings in 163 patients. Can Assoc Radiol J. 2017:68:276-85.

81. Joseph DK, Kunac A, Kinler RL, Staff I, Butler KL. Diagnosing blunt hollow viscus injury: is computed tomography the answer? Am J Surg. 2013;205:414-8.

82. Choi AY, Bodanapally UK, Shapiro B, Patlas MN, Katz DS. Recent advances in abdominal trauma computed tomography. Semin Roentgenol. 2018;53:178-86.
83. Rodriguez C, Barone JE, Wilbanks TO, Rha C-K, Miller K. Isolated free fluid on computed tomographic scan in blunt abdominal trauma: a systematic review of incidence and management. J Trauma. 2002;53:79-85.

84. Ballard RB, Badellino MM, Eynon CA, Spott MA, Staz CF, Buckman RF. Blunt duodenal rupture: a 6-year statewide experience. J Trauma. 1997;43:229-32 discussion 233.

85. Allen GS, Moore FA, Cox CS, Mehall JR, Duke JH. Delayed diagnosis of blunt duodenal injury: an avoidable complication. J Am Coll Surg. 1998;187:393-9.

86. Venkatesh SK, Wan JMC. CT of blunt pancreatic trauma: a pictorial essay. Eur J Radiol. 2008:67:311-20.

87. Gupta A, Stuhlfaut JW, Fleming KW, Lucey BC, Soto JA. Blunt trauma of the pancreas and biliary tract: a multimodality imaging approach to diagnosis. Radiographics. 2004;24:1381-95.

88. Brestas PS, Karakyklas D, Gardelis J, Tsouroulas M, Drossos C. Sequential CT evaluation of isolated non-penetrating pancreatic trauma. JOP. 2006;7:51-5.

89. Cirillo R, Koniaris LG. Detecting blunt pancreatic injuries. J Gastrointest Surg. 2002;6:587-98 Springer-Verlag.

90. Moschetta M, Telegrafo M, Malagnino V, Mappa L, lanora AAS, Dabbicco D, et al. Pancreatic trauma: the role of computed tomography for guiding therapeutic approach. World J Radiol. 2015;7:415-20.

91. Bradley M, Bonds B, Dreizin D, Colton K, Shanmuganathan K, Scalea TM, et al. Indirect signs of blunt duodenal injury on computed tomography: Is non-operative management safe? Injury. 2016:47:53-8.

92. Mahmood I, Tawfek Z, Abdelrahman Y, Siddiuqqi T, Abdelrahman H, El-Menyar A, et al. Significance of computed tomography finding of intra-abdominal free fluid without solid organ injury after blunt abdominal trauma: time for laparotomy on demand. World J Surg. 2014;38:1411-5.

93. Beierle EA, Chen MK, Whalen TV, Doolin EJ. Free fluid on abdominal computed tomography scan after blunt trauma does not mandate exploratory laparotomy in children. J Pediatr Surg. 2000;35:990-3.

94. Ng AKT, Simons RK, Torreggiani WC, Ho SGF, Kirkpatrick AW, Brown DRG. Intra-abdominal free fluid without solid organ injury in blunt abdominal trauma: an indication for laparotomy. J Trauma. 2002;52:1134-40.

95. Brofman N, Atri M, Hanson JM, Grinblat L, Chughtai T, Brenneman F. Evaluation of bowel and mesenteric blunt trauma with multidetector CT. Radiographics. 2006;26:1119-31.

96. Elbanna KY, Mohammed MF, Huang S-C, Mak D, Dawe JP, Joos E, et al. Delayed manifestations of abdominal trauma: follow-up abdominopelvic $C T$ in posttraumatic patients. Abdom Radiol. 2018:43:1642-55.

97. Rekhi S, Anderson SW, Rhea JT, Soto JA. Imaging of blunt pancreatic trauma. Emerg Radiol. 2010;17:13-9.

98. Leppäniemi AK, Haapiainen RK. Risk factors of delayed diagnosis of pancreatic trauma. Eur J Surg. 1999;165:1134-7.

99. Higashi H, Tamada T, Kanki A, Yamamoto A, Ito K. Hypovolemic shock complex: does the pancreatic perfusion increase or decrease at contrastenhanced dynamic CT? Clin Imaging. 2014;38:31-4.

100. Higashi H, Kanki A, Watanabe S, Yamamoto A, Noda Y, Yasokawa K, et al. Traumatic hypovolemic shock revisited: the spectrum of contrast-enhanced abdominal computed tomography findings and clinical implications for its management. Jpn J Radiol. 2014;32:579-84.

101. Stone TJ, Norbet C, Rhoades P, Bhalla S, Menias CO. Computed tomography of adult blunt abdominal and pelvic trauma: implications for treatment and interventions. Semin Roentgenol. 2014;49:186-201.

102. Stafford RE, McGonigal MD, Weigelt JA, Johnson TJ. Oral contrast solution and computed tomography for blunt abdominal trauma: a randomized study. Arch Surg. 1999;134:622-6 discussion 626-7.

103. Walker ML, Akpele I, Spence SD, Henderson V. The role of repeat computed tomography scan in the evaluation of blunt bowel injury. Am Surg. 2012;78: 979-85.

104. Fakhry SM, Brownstein M, Watts DD, Baker CC, Oller D. Relatively short diagnostic delays ( $(8 \mathrm{~h})$ produce morbidity and mortality in blunt small bowel injury: an analysis of time to operative interventions in 198 patients from a multicenter experience. J Trauma. 2000:48:408-14 discussion 414-5.

105. Velmahos GC, Tabbara M, Gross R, Willette P, Hirsch E, Burke P, et al. Blunt pancreatoduodenal injury: a multicenter study of the Research Consortium of New England Centers for Trauma (ReCONECT). Arch Surg. 2009;144:413-9 discussion 419-20

106. Fang JF, Chen RJ, Lin BC, Hsu YB, Kao JL, Kao YC, et al. Small bowel perforation: is urgent surgery necessary? J Trauma. 1999;47:515-20. 
107. Gillams AR, Kurzawinski T, Lees WR. Diagnosis of duct disruption and assessment of pancreatic leak with dynamic secretin-stimulated MR cholangiopancreatography. AJR Am J Roentgenol. 2006;186:499-506.

108. Sahni VA, Mortelé KJ. The bloody pancreas: MDCT and MRI features of hypervascular and hemorrhagic pancreatic conditions. AJR Am J Roentgenol. 2009;192:923-35.

109. Ragozzino A, Manfredi R, Scaglione M, De Ritis R, Romano S, Rotondo A. The use of MRCP in the detection of pancreatic injuries after blunt trauma Emerg Radiol. 2003;10:14-8.

110. Megibow AJ, Babb JS, Hecht EM, Cho JJ, Houston C, Boruch MM, et al. Evaluation of bowel distention and bowel wall appearance by using neutral oral contrast agent for multi-detector row CT. Radiology. 2006;238:87-95.

111. Ramsay DW, Markham DH, Morgan B, Rodgers PM, Liddicoat AJ. The use of dilute Calogen as a fat density oral contrast medium in upper abdominal computed tomography, compared with the use of water and positive oral contrast media. Clin Radiol. 2001;56:670-3.

112. Thompson SE, Raptopoulos V, Sheiman RL, McNicholas MM, Prassopoulos P. Abdominal helical CT: milk as a low-attenuation oral contrast agent. Radiology. 1999;211:870-5.

113. Zwaan M, Gmelin E, Borgis KJ, Rinast E. Non-absorbable fat-dense oral contrast agent for abdominal computed tomography. Eur J Radiol. 1992;14(3):189-91.

114. Malik N, Khandelwal N, Garg K, Suri S. Computed tomography of the abdomen with fat density oral contrast medium. Australas Radiol. 1992;36:31-3

115. Raptopoulos V, Davis MA, Davidoff A, Karellas A, Hays D, D'Orsi CJ, et al. Fatdensity oral contrast agent for abdominal CT. Radiology. 1987;164:653-6.

116. Allen TL, Mueller MT, Bonk RT, Harker CP, Duffy OH, Stevens MH. Computed tomographic scanning without oral contrast solution for blunt bowel and mesenteric injuries in abdominal trauma. J Trauma. 2004;56:314-22.

117. Stuhlfaut JW, Soto JA, Lucey BC, Ulrich A, Rathlev NK, Burke PA, et al. Blunt abdominal trauma: performance of $C T$ without oral contrast material. Radiology. 2004;233:689-94.

118. Lee $\mathrm{CH}$, Haaland $\mathrm{B}$, Earnest $\mathrm{A}$, Tan $\mathrm{CH}$. Use of positive oral contrast agents in abdominopelvic computed tomography for blunt abdominal injury: meta-analysis and systematic review. Eur Radiol. 2013;23:2513-21.

119. Victoria T, Mahboubi S. Normal appendiceal diameter in children: does choice of CT oral contrast (VoLumen versus Gastrografin) make a difference? Emerg Radiol. 2010;17:397-401.

120. Berther R, Patak MA, Eckhardt B, Erturk SM, Zollikofer CL. Comparison of neutral oral contrast versus positive oral contrast medium in abdominal multidetector CT. Eur Radiol. 2008;18:1902-9.

121. Erturk SM, Mortelé KJ, Oliva M-R, Ichikawa T, Silverman SG, Cantisani V, et al. Depiction of normal gastrointestinal anatomy with MDCT: comparison of low- and high-attenuation oral contrast media. Eur J Radiol. 2008;66:84-7.

122. Hebert JJ, Taylor AJ, Winter TC, Reichelderfer M, Weichert JP. Lowattenuation oral $\mathrm{Gl}$ contrast agents in abdominal-pelvic computed tomography. Abdom Imaging. 2006;31:48-53.

123. Halsted MJ, Racadio JM, Emery KH, Kreymerman P, Poe SA, Bean JA, et al. Oral contrast agents for $C T$ of abdominal trauma in pediatric patients: a comparison of dilute hypaque and water. AJR Am J Roentgenol. 2004;182: 1555-9.

124. Brody AS, Guillerman RP. Don't let radiation scare trump patient care: 10 ways you can harm your patients by fear of radiation-induced cancer from diagnostic imaging. Thorax. 2014;69:782-4.

125. Asensio JA, Petrone P, Roldán G, Pak-art R, Salim A. Pancreatic and duodenal injuries. complex and lethal. Scand J Surg. 2002;91:81-6.

126. Timaran $\mathrm{CH}$, Daley BJ, Enderson BL. Role of duodenography in the diagnosis of blunt duodenal injuries. J Trauma. 2001;51:648-51.

127. Keil R, Drabek J, Lochmannova J, Stovicek J, Rygl M, Snajdauf J, et al. What is the role of endoscopic retrograde cholangiopancreatography in assessing traumatic rupture of the pancreatic in children? Scand J Gastroenterol. 2016; 51:218-24.

128. Gagne S, O Sullivan-Murphy B, Lo HS, Mclntosh LJ. Pancreaticobiliary trauma: a multimodality imaging update. Semin Ultrasound CT MR. 2018;39: 355-62.

129. Shah S, Khosa F, Rai S, McLaughlin P, Louis L, Nicolaou S. Imaging blunt pancreatic and duodenal trauma. Appl Radiol. 2016;45(11):22-28.

130. Hofmann LJ, Learn PA, Cannon JW. Intraoperative ultrasound to assess for pancreatic duct injuries. J Trauma Acute Care Surg. 2015;78:888-91.

131. Jeroukhimov I, Zoarets I, Wiser I, Shapira Z, Abramovich D, Nesterenko V, et al. Diagnostic use of endoscopic retrograde cholangiopancreatectography for pancreatic duct injury in trauma patients. Isr Med Assoc J. 2015;17:401-4.

132. Panda A, Kumar A, Gamanagatti S, Bhalla AS, Sharma R, Kumar S, et al. Evaluation of diagnostic utility of multidetector computed tomography and magnetic resonance imaging in blunt pancreatic trauma: a prospective study. Acta Radiol. 2015;56:387-96

133. Lv F, Tang J, Luo Y, Nie Y, Liang T, Jiao Z, et al. Emergency contrastenhanced ultrasonography for pancreatic injuries in blunt abdominal trauma. Radiol Med. 2014;119:920-7.

134. Maeda K, Ono S, Baba K, Kawahara I. Management of blunt pancreatic trauma in children. Pediatr Surg Int. 2013;29:1019-22.

135. Hamidian Jahromi A, D'Agostino HR, Zibari GB, Chu QD, Clark C, ShokouhAmiri H. Surgical versus nonsurgical management of traumatic major pancreatic duct transection: institutional experience and review of the literature. Pancreas. 2013:42:76-87.

136. Kokabi N, Shuaib W, Xing M, Harmouche E, Wilson K, Johnson J-O, et al. Intra-abdominal solid organ injuries: an enhanced management algorithm. Can Assoc Radiol J. 2014;65:301-9.

137. Rosenfeld EH, Vogel AM, Klinkner DB, Escobar M, Gaines B, Russell R, et al. The utility of ERCP in pediatric pancreatic trauma. J Pediatr Surg. 2017:53:146-51.

138. Lin TK, Troendle DM, Wallihan DB, Barth B, Fox VL, Fishman DS, et al. Specialized imaging and procedures in pediatric pancreatology: a North American Society for Pediatric Gastroenterology, Hepatology, and Nutrition Clinical Report. J Pediatr Gastroenterol Nutr. 2017;64:472-84.

139. Garvey EM, Haakinson DJ, McOmber M, Notrica DM. Role of ERCP in pediatric blunt abdominal trauma: a case series at a level one pediatric trauma center. J Pediatr Surg. 2015;50:335-8

140. Lee PH, Lee SK, Kim GU, Hong S-K, Kim J-H, Hyun Y-S, et al. Outcomes of hemodynamically stable patients with pancreatic injury after blunt abdominal trauma. Pancreatology. 2012;12:487-92.

141. Sharma AK. Management of pancreaticoduodenal injuries. Indian J Surg. 2012;74:35-9.

142. Soto JA, Anderson SW. Multidetector CT of blunt abdominal trauma. Radiology. 2012;265:678-93.

143. Scaglione M, Romano L, Bocchini G, Sica G, Guida F, Pinto A, et al. Multidetector computed tomography of pancreatic, small bowel, and mesenteric traumas. Semin Roentgenol. 2012;47:362-70.

144. Halefoglu A-M. Magnetic resonance cholangiopancreatography: a useful tool in the evaluation of pancreatic and biliary disorders. World J Gastroenterol. 2007;13:2529-34

145. Schellenberg M, Inaba K, Bardes JM, Cheng V, Matsushima K, Lam L, et al. Detection of traumatic pancreatic duct disruption in the modern era. Am J Surg. 2018;216:299-303 Elsevier.

146. Bates DDB, LeBedis CA, Soto JA, Gupta A. Use of magnetic resonance in pancreaticobiliary emergencies. Magn Reson Imaging Clin N Am. 2016:24:433-48

147. Biffl WL, Moore EE, Croce M, Davis JW, Coimbra R, Karmy-Jones R, et al. Western Trauma Association critical decisions in trauma: management of pancreatic injuries. J Trauma Acute Care Surg. 2013;75:941-6.

148. Lin TK, Barth BA. Endoscopic retrograde cholangiopancreatography in pediatrics. Tech Gastrointest Endosc. 2013;15:41-6.

149. Holalkere N-S, Soto J. Imaging of miscellaneous pancreatic pathology (trauma, transplant, infections, and deposition). Radiol Clin North Am. 2012; 50:515-28.

150. Cazauran J-B, Muller A, Hengy B, Valette P-J, Gruner L, Monneuse O. Preliminary report of percutaneous cholecystostomy as diagnosis and treatment of biliary tract trauma. World J Surg. 2018;42:3705-14.

151. Melamud K, LeBedis CA, Anderson SW, Soto JA. Biliary imaging: multimodality approach to imaging of biliary injuries and their complications. Radiographics. 2014;34:613-23.

152. Enestvedt BK, Tofani C, Lee DY, Abraham M, Shah P, Chandrasekhara $V$, et al. Endoscopic retrograde cholangiopancreatography in the pediatric population is safe and efficacious. J Pediatr Gastroenterol Nutr. 2013;57:649-54

153. Choron RL, Efron DT. Isolated and combined duodenal and pancreatic injuries: a review and update. Curr Surg Reports. 2018;6:65-68.

154. Lin B-C, Wong Y-C, Chen R-J, Liu N-J, Wu C-H, Hwang T-L, et al. Major pancreatic duct continuity is the crucial determinant in the management of blunt pancreatic injury: a pancreatographic classification. Surg Endosc. 2017; 31:4201-10. 
155. Ho VP, Patel NJ, Bokhari F, Madbak FG, Hambley JE, Yon JR, et al. Management of adult pancreatic injuries: a practice management guideline from the Eastern Association for the Surgery of Trauma. J Trauma Acute Care Surg. 2017:82:185-99.

156. DiGiacomo L, Schreiber MA. Penetrating pancreatic injury. Curr Trauma Rep. 2015;1:85-91.

157. Notrica DM. Pediatric blunt abdominal trauma: current management. Curr Opin Crit Care. 2015;21:531-7.

158. Scheers I, Ergun M, Aouattah T, Piessevaux H, Borbath I, Stephenne X, et al. Diagnostic and therapeutic roles of endoscopic ultrasound in pediatric pancreaticobiliary disorders. J Pediatr Gastroenterol Nutr. 2015;61:238-47.

159. Hayward SR, Lucas CE, Sugawa C, Ledgerwood AM. Emergent endoscopic retrograde cholangiopancreatography: a highly specific test for acute pancreatic trauma. Arch Surg. 1989;124:745-6.

160. Wisner DH, Chun Y, Blaisdell FW. Blunt intestinal injury. Keys to diagnosis and management. Arch Surg. 1990;125:1319-22 discussion 1322-3.

161. Munns J, Richardson M, Hewett P. A review of intestinal injury from blunt abdominal trauma. Aust N Z J Surg. 1995;65:857-60.

162. Fang JF, Chen RJ, Lin BC. Cell count ratio: new criterion of diagnostic peritoneal lavage for detection of hollow organ perforation. J Trauma. 1998; 45:540-4

163. Catre MG. Diagnostic peritoneal lavage versus abdominal computed tomography in blunt abdominal trauma: a review of prospective studies. Can J Surg. 1995;38:117-22.

164. Bain IM, Kirby RM. 10 year experience of splenic injury: an increasing place for conservative management after blunt trauma. Injury. 1998;29:177-82.

165. Falcone RE, Thomas B, Hrutkay L. Safety and efficacy of diagnostic peritoneal lavage performed by supervised surgical and emergency medicine residents. Eur J Emerg Med. 1997;4:150-5.

166. Chereau N, Wagner M, Tresallet C, Lucidarme O, Raux M, Menegaux F. CT scan and diagnostic peritoneal lavage: towards a better diagnosis in the area of nonoperative management of blunt abdominal trauma. Injury. 2016; 47:2006-11.

167. Zantut LF, Ivatury RR, Smith RS, Kawahara NT, Porter JM, Fry WR, et al. Diagnostic and therapeutic laparoscopy for penetrating abdominal trauma: a multicenter experience. J Trauma. 1997;42:825-9 discussion 829-31.

168. Johnson JJ, Garwe T, Raines AR, Thurman JB, Carter S, Bender JS, et al. The use of laparoscopy in the diagnosis and treatment of blunt and penetrating abdominal injuries: 10-year experience at a level 1 trauma center. Am J Surg. 2013;205:317-20 discussion 321

169. Zafar SN, Onwugbufor MT, Hughes K, Greene WR, Cornwell EE, Fullum TM, et al. Laparoscopic surgery for trauma: the realm of therapeutic management. Am J Surg. 2015;209:627-32.

170. Justin V, Fingerhut A, Uranues S. Laparoscopy in blunt abdominal trauma: for whom? when? and why? Curr Trauma Rep. 2017;3:43-50.

171. Chen G, Yang H. Management of duodenal trauma. Chinese J Traumatol. 2011;14:61-4.

172. Brotman S, Cisternino S, Myers RA, Cowley RA. A test to help diagnosis of rupture in the injured duodenum. Injury. 1981;12:464-5.

173. Parks RW, Diamond T. Non-surgical trauma to the extrahepatic biliary tract. Br J Surg. 1995;82:1303-10.

174. Ivatury RR, Nallathambi M, Gaudino J, Rohman M, Stahl WM. Penetrating duodenal injuries. Ann Surg. 1985;202:153-8.

175. Ivatury RR, Nallathambi M, Rao P, Stahl WM. Penetrating pancreatic injuries Analysis of 103 consecutive cases. Am Surg. 1990;56:90-5.

176. Ivatury RR, Simon RJ, Guignard J, Kazigo J, Gunduz Y, Stahl WM. The spleen at risk after penetrating trauma. J Trauma Inj Infect Crit Care. 1993;35:409-14.

177. Nassoura ZE, Ivatury RR, Simon RJ, Kihtir T, Stahl WM. A prospective reappraisal of primary repair of penetrating duodenal injuries. Am Surg. 1994;60:35-9.

178. Ivatury RR, Nassoura ZE, Simon RJ, Rodriguez A. Complex duodenal injuries. Surg Clin North Am. 1996;76:797-812.

179. Fulcher AS, Turner MA, Yelon JA, McClain LC, Broderick T, Ivatury RR, et al. Magnetic resonance cholangiopancreatography (MRCP) in the assessment of pancreatic duct trauma and its sequelae: preliminary findings. J Trauma. 2000;48:1001-7.

180. Ivatury RR, Malhotra AK, Aboutanos MB, Duane TM. Duodenal injuries: a review. Eur J Trauma Emerg Surg. 2007;33:231-7.

181. Ferrada P, Wolfe L, Duchesne J, Fraga GP, Benjamin E, Alvarez A, et al. Management of duodenal trauma: a retrospective review from the Panamerican Trauma Society. J Trauma Acute Care Surg. 2019;86:392-6.
182. Ivatury RR, Gaudino J, Ascer E, Nallathambi M, Ramirez-Schon G, Stahl WM Treatment of penetrating duodenal injuries: primary repair vs. repair with decompressive enterostomy/serosal patch. J Trauma. 1985;25:337-41.

183. Ivatury RR, Rohman M, Nallathambi M, Rao PM, Gunduz Y, Stahl WM. The morbidity of injuries of the extra-hepatic biliary system. J Trauma Inj Infect Crit Care. 1985:25:967-73.

184. O'Reilly DA, Bouamra O, Kausar A, Malde DJ, Dickson EJ, Lecky F. The epidemiology of and outcome from pancreatoduodenal trauma in the UK, 1989-2013. Ann R Coll Surg Engl. 2015;97:125-30.

185. Peterson ML, Abbas PI, Fallon SC, Naik-Mathuria BJ, Rodriguez JR. Management of traumatic duodenal hematomas in children. J Surg Res. 2015;199:126-9.

186. Carrillo EH, Richardson JD, Miller FB. Evolution in the management of duodenal injuries. J Trauma. 1996;40:1037-45 discussion 1045-6.

187. Malhotra A, Biffl WL, Moore EE, Schreiber M, Albrecht RA, Cohen M, et al. Western Trauma Association Critical Decisions in Trauma: diagnosis and management of duodenal injuries. J Trauma Acute Care Surg. 2015;79:1096-101.

188. Nolan GJ, Bendinelli C, Gani J. Laparoscopic drainage of an intramural duodenal haematoma: a novel technique and review of the literature. World J Emerg Surg. 2011:6:42.

189. Patterson VM, Goettler CE, Thomas CC. Traumatic duodenal hematoma in a pediatric patient treated by percutaneous drainage. Am Surg. 2011;77:E220-1.

190. Moon S-B, Jung S-E, Cheon J-E, Kim W-S, Park K-W. Very large traumatic duodenal hematoma: successful percutaneous drainage in a child. Eur J Pediatr Surg. 2009;19:412-3.

191. Yang JC, Rivard DC, Morello FP, Ostlie DJ. Successful percutaneous drainage of duodenal hematoma after blunt trauma. J Pediatr Surg. 2008:43:e13-5.

192. Gullotto C, Paulson EK. CT-guided percutaneous drainage of a duodenal hematoma. AJR Am J Roentgenol. 2005:184:231-3.

193. Hanish SI, Pappas TN. CT guided drainage of a duodenal hematoma after trauma. J Trauma. 2007:63:E10-2.

194. Clendenon JN, Meyers RL, Nance ML, Scaife ER. Management of duodenal injuries in children. J Pediatr Surg. 2004;39:964-8.

195. Jurić I, Pogorelić Z, Biocić M, Todorić D, Furlan D, Susnjar T. Management of blunt pancreatic trauma in children. Surg Today. 2009:39:115-9.

196. Duchesne JC, Schmieg R, Islam S, Olivier J, McSwain N. Selective nonoperative management of low-grade blunt pancreatic injury: are we there yet? J Trauma. 2008;65:49-53.

197. Mattix KD, Tataria M, Holmes J, Kristoffersen K, Brown R, Groner J, et al. Pediatric pancreatic trauma: predictors of nonoperative management failure and associated outcomes. J Pediatr Surg. 2007;42:340-4.

198. Iqbal CW, St Peter SD, Tsao K, Cullinane DC, Gourlay DM, Ponsky TA, et al. Operative vs nonoperative management for blunt pancreatic transection in children: multi-institutional outcomes. J Am Coll Surg. 2014;218:157-62.

199. Lin B-C, Chen R-J, Fang J-F, Hsu Y-P, Kao Y-C, Kao J-L. Management of blunt major pancreatic injury. J Trauma. 2004:56:774-8.

200. Wood JH, Partrick DA, Bruny JL, Sauaia A, Moulton SL. Operative vs nonoperative management of blunt pancreatic trauma in children. J Pediatr Surg. 2010;45:401-6

201. Björnsson B, Kullman E, Gasslander T, Sandström P. Early endoscopic treatment of blunt traumatic pancreatic injury. Scand J Gastroenterol. 2015; 50:1435-43.

202. Telford JJ, Farrell JJ, Saltzman JR, Shields SJ, Banks PA, Lichtenstein DR, et al. Pancreatic stent placement for duct disruption. Gastrointest Endosc. 2002; 56:18-24.

203. Kong Y, Zhang H, He X, Liu C, Piao L, Zhao G, et al. Endoscopic management for pancreatic injuries due to blunt abdominal trauma decreases failure of nonoperative management and incidence of pancreatic-related complications. Injury. 2014;45:134-40.

204. Rogers SJ, Cello JP, Schecter WP. Endoscopic retrograde cholangiopancreatography in patients with pancreatic trauma. J Trauma Inj Infect Crit Care. 2010;68:538-44.

205. Coelho DE, Ardengh JC, Carbalo MT, de Lima-Filho ER, Baron TH, Coelho JF. Clinicopathologic characteristics and endoscopic treatment of posttraumatic pancreatic pseudocysts. Pancreas. 2011:40:469-73.

206. Malick KJ. Endoscopic management of pancreatic pseudocysts. Gastroenterol Nurs. 2005:28:298-303 quiz 304-5.

207. Lin B-C, Fang J-F, Wong Y-C, Liu N-J. Blunt pancreatic trauma and pseudocyst: management of major pancreatic duct injury. Injury. 2007; 38:588-93. 
208. Koganti SB, Kongara R, Boddepalli S, Mohammad NS, Thumma V, Nagari B, et al. Predictors of successful non-operative management of grade III \&amp; IV blunt pancreatic trauma. Ann Med Surg. 2016;10:103-9.

209. Lin B-C, Liu N-J, Fang J-F, Kao Y-C. Long-term results of endoscopic stent in the management of blunt major pancreatic duct injury. Surg Endosc. 2006; 20:1551-5.

210. Bozkurt B, Ozdemir BA, Kocer B, Unal B, Dolapci M, Cengiz O. Operative approach in traumatic injuries of the duodenum. Acta Chir Belg. 2006;106(4):405-8

211. Talving P, Nicol AJ, Navsaria PH. Civilian duodenal gunshot wounds: surgical management made simpler. World J Surg. 2006;30:488-94.

212. Ordoñez C, García A, Parra MW, Scavo D, Pino LF, Millán M, et al. Complex penetrating duodenal injuries: less is better. J Trauma Acute Care Surg. 2014;76:1177-83.

213. Cogbill TH, Moore EE, Feliciano DV, Hoyt DB, Jurkovich GJ, Morris JA, et al. Conservative management of duodenal trauma: a multicenter perspective. J Trauma. 1990;30:1469-75.

214. Velmahos GC, Constantinou C, Kasotakis G. Safety of repair for severe duodenal injuries. World J Surg. 2008;32:7-12.

215. DuBose JJ, Inaba K, Teixeira PGR, Shiflett A, Putty B, Green DJ, et al. Pyloric exclusion in the treatment of severe duodenal injuries: results from the National Trauma Data Bank. Am Surg. 2008;74:925-9.

216. Lopez PP, Benjamin R, Cockburn M, Amortegui JD, Schulman Cl, Soffer D, et al. Recent trends in the management of combined pancreatoduodenal injuries. Am Surg. 2005;71:847-52.

217. Mayberry J, Fabricant L, Anton A, Ham B, Schreiber M, Mullins R. Management of full-thickness duodenal laceration in the damage control era: evolution to primary repair without diversion or decompression. Am Surg. 2011;77:681-5.

218. Stone HH, Fabian TC. Management of duodenal wounds. J Trauma. 1979;19:334-9.

219. Berne CJ, Donovan AJ, White EJ, Yellin AE. Duodenal "diverticulization" for duodenal and pancreatic injury. Am J Surg. 1974;127:503-7.

220. Vaughan GD, Frazier OH, Graham DY, Mattox KL, Petmecky FF, Jordan GL. The use of pyloric exclusion in the management of severe duodenal injuries. Am J Surg. 1977;134:785-90.

221. Ginzburg E, Carrillo EH, Sosa JL, Hertz J, Nir I, Martin LC. Pyloric exclusion in the management of duodenal trauma: is concomitant gastrojejunostomy necessary? Am Surg. 1997;63:964-6.

222. Martin TD, Feliciano DV, Mattox KL, Jordan GL. Severe duodenal injuries: treatment with pyloric exclusion and gastrojejunostomy. Arch Surg. 1983; 118:631-5.

223. Cruvinel Neto J, Pereira BMT, Ribeiro MAF, Rizoli S, Fraga GP, Rezende-Neto JB. Is there a role for pyloric exclusion after severe duodenal trauma? Rev Col Bras Cir. 2014:41(3):228-31.

224. Seamon MJ, Pieri PG, Fisher CA, Gaughan J, Santora TA, Pathak AS, et al. A ten-year retrospective review: does pyloric exclusion improve clinical outcome after penetrating duodenal and combined pancreaticoduodenal injuries? J Trauma. 2007;62:829-33.

225. Girgin S, Gedik E, Yağmur Y, Uysal E, Baç B. Management of duodenal injury: our experience and the value of tube duodenostomy. Ulus Travma Acil Cerrahi Derg. 2009;15:467-72.

226. Degiannis E, Boffard K. Duodenal injuries. Br J Surg. 2000;87:1473-9.

227. Krige JE, Nicol AJ, Navsaria PH. Emergency pancreatoduodenectomy for complex injuries of the pancreas and duodenum. HPB (Oxford). 2014;16: 1043-9.

228. Krige JE, Navsaria PH, Nicol AJ. Damage control laparotomy and delayed pancreatoduodenectomy for complex combined pancreatoduodenal and venous injuries. Eur J Trauma Emerg Surg. 2016;42:225-30.

229. Krige JE, Kotze UK, Setshedi M, Nicol AJ, Navsaria PH. Surgical management and outcomes of combined pancreaticoduodenal injuries: analysis of 75 consecutive cases. J Am Coll Surg. 2016;222:737-49.

230. Thompson CM, Shalhub S, DeBoard ZM, Maier RV. Revisiting the pancreaticoduodenectomy for trauma: a single institution's experience. J Trauma Acute Care Surg. 2013;75:225-8

231. Gulla A, Tan WP, Pucci MJ, Dambrauskas Z, Rosato EL, Kaulback KR, et al. Emergent pancreaticoduodenectomy: a dual institution experience and review of the literature. J Surg Res. 2014;186:1-6.

232. Dickerson RN, Voss JR, Schroeppel TJ, Maish GO, Magnotti LJ, Minard G, et al. Feasibility of jejunal enteral nutrition for patients with severe duodenal injuries. Nutrition. 2016;32:309-14.
233. Krige JEJ, Kotze UK, Nicol AJ, Navsaria PH. Morbidity and mortality after distal pancreatectomy for trauma: a critical appraisal of 107 consecutive patients undergoing resection at a Level 1 Trauma Centre. Injury. 2014;45: 1401-8.

234. Fabian TC, Kudsk KA, Croce MA, Payne LW, Mangiante EC, Voeller GR, et al. Superiority of closed suction drainage for pancreatic trauma. A randomized, prospective study. Ann Surg. 1990;211:724-8 discussion 728-30.

235. Malgras B, Douard R, Siauve N, Wind P. Management of left pancreatic trauma. Am Surg. 2011;77:1-9.

236. Schellenberg M, Inaba K, Cheng V, Bardes JM, Lam L, Benjamin E, et al. Spleen-preserving distal pancreatectomy in trauma. J Trauma Acute Care Surg. 2018;84:118-22.

237. Nikfarjam M, Rosen M, Ponsky T. Early management of traumatic pancreatic transection by spleen-preserving laparoscopic distal pancreatectomy. J Pediatr Surg. 2009;44:455-8.

238. Leva E, Huscher C, Rode H, Fava G, Napolitano M, Maestri L, et al. Management of traumatic complete pancreatic fracture in a child: case report and review of literature. J Laparoendosc Adv Surg Tech A. 2008;18: 321-3.

239. Sharpe JP, Magnotti LJ, Weinberg JA, Zarzaur BL, Stickley SM, Scott SE, et al. Impact of a defined management algorithm on outcome after traumatic pancreatic injury. J Trauma Acute Care Surg. 2012;72:100-5.

240. Krige JEJ, Kotze UK, Hameed M, Nicol AJ, Navsaria PH. Pancreatic injuries after blunt abdominal trauma: an analysis of 110 patients treated at a level 1 trauma centre. S Afr J Surg. 2011;49:58-60 62-4 passim.

241. Buccimazza I, Thomson SR, Anderson F, Naidoo NM, Clarke DL. Isolated main pancreatic duct injuries spectrum and management. Am J Surg. 2006; 191:448-52.

242. Chinnery GE, Thomson SR, Ghimenton F, Anderson F. Pancreaticoenterostomy for isolated main pancreatic duct disruption. Injury. 2008; 39:50-6.

243. Seamon MJ, Kim PK, Stawicki SP, Dabrowski GP, Goldberg AJ, Reilly PM, et al. Pancreatic injury in damage control laparotomies: Is pancreatic resection safe during the initial laparotomy? Injury. 2009:40:61-5.

244. Asensio JA, Petrone P, Roldán G, Kuncir E, Demetriades D. Pancreaticoduodenectomy: a rare procedure for the management of complex pancreaticoduodenal injuries. J Am Coll Surg. 2003;197:937-42.

245. Bao W-Y, She G, Duan Y-F, Liu S-Y, Sun D-L, Yang Y, et al. Diagnosis and management of high-grade pancreatic trauma: report of 14 cases. Indian J Surg. 2015;77:1222-6.

246. van der Wilden GM, Yeh DD, Hwabejire JO, Klein EN, Fagenholz PJ, King DR, et al. Trauma Whipple: do or don't after severe pancreaticoduodenal injuries? An analysis of the National Trauma Data Bank (NTDB). World J Surg 2014:38:335-40.

247. Nabi Z, Lakhtakia S, Basha J, Chavan R, Gupta R, Ramchandani M, et al. Endoscopic drainage of pancreatic fluid collections: long-term outcomes in children. Dig Endosc. 2017:29:790-7.

248. Almeida RR, Lo GC, Patino M, Bizzo B, Canellas R, Sahani DV. Advances in pancreatic CT imaging. AJR Am J Roentgenol. 2018;211:52-66.

249. Miele V, Piccolo CL, Galluzzo M, lanniello S, Sessa B, Trinci M. Contrastenhanced ultrasound (CEUS) in blunt abdominal trauma. Br J Radiol. 2016; 89:20150823.

250. Tkacz JN, Anderson SA, Soto J. MR imaging in gastrointestinal emergencies. Radiographics. 2009;29:1767-80.

251. Nicolau C, Ripollés T. Contrast-enhanced ultrasound in abdominal imaging. Abdom Imaging. 2012;37:1-19.

252. Valentino M, De Luca C, Galloni SS, Branchini M, Modolon C, Pavlica P, et al. Contrast-enhanced US evaluation in patients with blunt abdominal trauma. J Ultrasound. 2010;13:22-7.

253. Makin E, Harrison PM, Patel S, Davenport M. Pancreatic pseudocysts in children: treatment by endoscopic cyst gastrostomy. J Pediatr Gastroenterol Nutr. 2012:55:556-8.

254. Zhou J, Huang J, Wu H, Jiang H, Zhang H, Prasoon P, et al. Screening ultrasonography of 2,204 patients with blunt abdominal trauma in the Wenchuan earthquake. J Trauma Acute Care Surg. 2012;73:890-4.

255. Valentino M, Ansaloni L, Catena F, Pavlica P, Pinna AD, Barozzi L. Contrastenhanced ultrasonography in blunt abdominal trauma: considerations after 5 years of experience. Radiol Med. 2009;114:1080-93.

256. Weiser R, Pencovich N, Mlynarsky L, Berliner-Senderey A, Lahat G, Santo E, et al. Management of endoscopic retrograde cholangiopancreatographyrelated perforations: experience of a tertiary center. Surgery. 2017;161:920-9. 
257. Abbo O, Lemandat A, Reina N, Bouali O, Ballouhey Q, Carfagna L, et al. Conservative management of blunt pancreatic trauma in children: a single center experience. Eur J Pediatr Surg. 2013;23:470-3.

258. Beres AL, Wales PW, Christison-Lagay ER, McClure ME, Fallat ME, Brindle ME. Non-operative management of high-grade pancreatic trauma: is it worth the wait? J Pediatr Surg. 2013:48:1060-4.

259. Krige JEJ, Kotze UK, Nicol AJ, Navsaria PH. Isolated pancreatic injuries: an analysis of 49 consecutive patients treated at a Level 1 Trauma Centre. J Visc Surg. 2015;152:349-55.

260. Krige JEJ, Kotze UK, Setshedi M, Nicol AJ, Navsaria PH. Prognostic factors, morbidity and mortality in pancreatic trauma: a critical appraisal of 432 consecutive patients treated at a Level 1 Trauma Centre. Injury. 2015:46:830-6.

261. Braha J, Tenner S. Fluid collections and pseudocysts as a complication of acute pancreatitis. Gastrointest Endosc Clin N Am. 2018:28:123-30.

262. Mutignani M, Dokas S, Tringali A, Forti E, Pugliese F, Cintolo M, et al. Pancreatic leaks and fistulae: an endoscopy-oriented classification. Dig Dis Sci. 2017:62:2648-57.

263. Mansfield N, Inaba K, Berg R, Beale E, Benjamin E, Lam L, et al. Early pancreatic dysfunction after resection in trauma: an 18-year report from a Level I trauma center. J Trauma Acute Care Surg. 2017;82:528-33.

264. Morita T, Takasu O, Sakamoto T, Mori S, Nakamura A, Nabeta M, et al. Longterm outcomes of pancreatic function following pancreatic trauma. Kurume Med J. 2017;63:53-60.

265. Katz MG, Fenton SJ, Russell KW, Scaife ER, Short SS. Surgical outcomes of pancreaticoduodenal injuries in children. Pediatr Surg Int. 2018;34:641-5.

\section{Publisher's Note}

Springer Nature remains neutral with regard to jurisdictional claims in published maps and institutional affiliations.

Ready to submit your research? Choose BMC and benefit from:

- fast, convenient online submission

- thorough peer review by experienced researchers in your field

- rapid publication on acceptance

- support for research data, including large and complex data types

- gold Open Access which fosters wider collaboration and increased citations

- maximum visibility for your research: over $100 \mathrm{M}$ website views per year

At BMC, research is always in progress.

Learn more biomedcentral.com/submissions 